\title{
Comparison of sediment rating curves and sediment yield in subbasins of the Itacaiúnas River Watershed, Eastern Amazon
}

\section{Comparação da curva-chave de sedimentos e produção de sedimentos em sub-bacias da bacia hidrográfica do rio Itacaiúnas, Amazônia Oriental}

\author{
Marcio Sousa da Silva ${ }^{1,2}$ (D), Rosane Lopes Cavalcante ${ }^{1}$ (D), Pedro Walfir Martins e Souza Filho ${ }^{1,2}$ (D), \\ Renato Oliveira da Silva Júnior ${ }^{1}$ (D), Paulo Rógenes Pontes $^{1}$ (D), Roberto Dallagnol ${ }^{1,2}$ (D) \& Edson José Paulino da Rocha ${ }^{2}$ (D) \\ ${ }^{1}$ Instituto Tecnológico Vale, Belém, PA, Brasil. \\ ${ }^{2}$ Universidade Federal do Pará, Belém, PA, Brasil. \\ E-mails: marcio.sousa.silva@itv.org (MSS), rosanecavalcante@gmail.com (RLC),pedro.martins.souza@itv.org (PWMSF), \\ renato.silva.junior@itv.org (ROSJ), p.rogenes@gmail.com (PRP), roberto.dallagnol@itv.org (RD), eprocha@ufpa.br (EJPR)
}

\begin{abstract}
Understanding the hydrosedimentological dynamics of tropical rivers is a challenge in the Amazon due to its remote and difficult-toaccess areas. This study was based on data collected from 16 hydrosedimentological control sections in the 6 subbasins that make up the Itacaiúnas River Watershed (IRW), with 4 annual campaigns (high water levels, rising water levels, falling water levels, low water levels) between 2015 and 2019, with the aim of constructing and comparing sediment rating curves and sediment yield. The data at the mouth of the IRW revealed that the rainy season is responsible for $93 \%$ of liquid discharges (Q) with an average of $1460.88 \mathrm{~m}^{3} / \mathrm{s}$ and for $98 \%$ of suspended sediment discharges (SSQ) with an average of 5864.15 tons/day. Suspended sediment concentrations (SSCs) are low to moderate (50 to $150 \mathrm{mg} / \mathrm{l})$. The curves encompassing all the data showed $\mathrm{R}^{2}$ values $(0.92$ to 0.99$)$ greater than the curves with only the values of the rainy or dry season, indicating a good fit of the power equation to the SSQ and Q data for all sections studied. Higher values of coefficients a and b show areas of greater sediment production and deforestation, as well as areas with new sources of sediment and preserved forest.
\end{abstract}

Keywords: Streamflow; Sediments; Specific sediment yield; Sediment rating curve; Itacaiúnas. River.

\section{RESUMO}

Compreender a dinâmica hidrossedimentológica dos rios tropicais é um desafio, principalmente na Amazônia, devido às suas áreas remotas e de difícil acesso. Este estudo foi baseado em dados coletados em 16 seções hidrossedimentológicas de controle distribuídas nas 6 sub-bacias que compõem a bacia hidrográfica do Rio Itacaiúnas (BHRI), com 4 campanhas anuais (enchente, cheia, vazante e seca) entre 2015 e 2019, objetivando a construção e comparação da curva-chave de sedimentos e produção de sedimentos. Os dados na foz da bacia revelaram que o período chuvoso é responsável por 93\% das descargas líquidas com médias de 1460,88 $\mathrm{m}^{3} / \mathrm{s}$ e por 98\% das descargas de sedimentos em suspensão com média de 5864,15 ton/dia. As Concentrações de sedimentos em suspensão (CSSs) são baixas a moderadas (50 a $150 \mathrm{mg} / \mathrm{l}$ ). As análises das curvas obtidas com todos os dados apresentaram $\mathrm{R}^{2}(0,92$ a 0,99$)$ maiores do que utilizando apenas os valores da estação chuvosa ou seca, mostrando um bom ajuste da equação de potência aos dados QSS e Q para todas as seções estudadas. Os maiores valores do coeficiente a e b indicam áreas de maior produção de sedimentos e desmatamento e áreas com novas fontes de sedimentos e floresta preservada.

Palavras-chave: Vazão; Sedimentos; Produção específica de sedimentos; Curva-chave de sedimentos; Rio Itacaiúnas. 


\section{INTRODUCTION}

Understanding the dynamics of hydrosedimentological processes in watersheds is critical for decision-making and supports management planning for the rational use of natural resources (Vestena, 2009). Knowing the behaviors and amounts of water (liquid discharge) and transported sediments (solid load) in different sectors of a watershed is important for the installation of hydraulic, environmental, and water resource projects, including the implementation of soil conservation and management techniques (Carvalho, 2008; Lohani et al., 2007). The sediment yield of a watershed depends on its natural characteristics, such as topography, soil type, land use and cover, and rainfall amount and intensity (Santos, 2015), as well as anthropogenic factors. These factors affect the amount of sediments generated by bank and channel erosion, the distances traveled by the sediments, the storage/mobilization of available sediments, and the sedimentation rate (Williams, 1989; Reid et al., 1997; Vestena, 2009).

Monitoring sediment flows in a given location in the watershed enables us to diagnose possible impacts on its drainage area over time, which can become an important environmental indicator. In river courses, approximately $80 \%$ of all sediment transport occurs during strong rainfall (Carvalho, 1994). Suspended sediment discharge, on average, may account for 70 to $95 \%$ of the total solid discharge, depending on the position of the watercourse cross-section and other factors (Carvalho et al., 2000).

One of the most comprehensive ways to qualify and quantify the intensity of the impacts of soil erosion on a watershed is by hydrosedimentological data collection and/or monitoring. The values of suspended solid discharge, suspended sediment concentration (SSC), and other parameters derived from hydrosedimentological studies (e.g., sediment yield, land use, and riverbed degradation) are applicable to many fields of study (Oliveira \& Cabral, 2011; Garrido et al., 2018).

Comparing different cross-sections along rivers under specific flow conditions, or flow frequency analysis, is highly important for understanding fluvial dynamics and equilibrium conditions (Aguiar, 2009). Accordingly, streamflow is the most significant parameter for any discussion regarding fluvial dynamics.

The transport of sediments and soluble materials, which corresponds to the watershed's fluvial mass transport, is generally the dominant factor in the watershed mass balance, in which the greatest sediment load is derived from weathering (Allen, 1997 apud Aguiar, 2009). The total material transported by the river can be satisfactorily determined by measuring the concentration of sediments, either deposited in the channel bed or suspended, depending on the turbulent water flow.

Traditionally, solid discharge is determined using sediment rating curves, which relate suspended solid discharge to liquid discharge (Carvalho, 1994; Glysson, 1987). According to Colby (1957), although sediment discharge sampling is performed seasonally, constructing a continuous curve for these discharges is justified because discharge occurs over the typical current flow range. Accordingly, sediment discharge or concentration can be plotted as a function of current flow at various sampling times to define an average sediment discharge or sediment concentration curve for a cross-section.
Hydrosedimentological data collected in the field are required to validate empirical and mathematical models that estimate soil erosion at the river basin scale, such as the Universal Soil Loss Equation (USLE; USLE and variations thereof - Benavidez et al., 2018; Alewell et al., 2019) and hydrological models coupled with soil loss equations. The USLE and its variations (the Revised Universal Soil Loss Equation - RUSLE; the Revised Universal Soil Loss Equation 2 - RUSLE2; and the Modified Universal Soil Loss Equation - MUSLE) are empirical models widely used to estimate annual soil erosion rates as a function of rainfall erosivity, soil erodibility, slope, land cover, management practices and soil conservation or prevention practices.

Additionally, hydrological models coupled with soil erosion equations are widely used because they allow estimating both soil loss production and transport through the use of flow routing methods. Some hydrological models are coupled with soil erosion equations, including SWAT (Arnold et al., 1998), MGB-SED (Buarque, 2015; Fagundes et al., 2020a, b), SWIM (Krysanova et al., 1996), and LASCAM (Viney \& Sivapalan, 1999). Sediment data are also used to calibrate statistical models related to the suspended sediment concentration and surface spectral reflectance (Fassoni-Andrade \& Paiva, 2019) obtained by multispectral instruments aboard satellites (Moderate Resolution Imaging Spectroradiometer, 2021).

In this context, the present study evaluates the hydrosedimentological dynamics of the Itacaiúnas River Watershed (IRW) in 16 control sections. The watershed has a land use typical of the Amazon arc of deforestation, in which protected areas and deforested areas are used predominantly for extensive grazing. Additionally, the region has great economic importance due to mineral activities. Liquid discharge and SSC monitoring data are used to determine seasonal sediment discharges and construct sediment rating curves.

\section{METHODS AND ANALYSES}

\section{Study site description}

The IRW encompasses an area of approximately $42,000 \mathrm{~km}^{2}$ in Carajás Mineral Province in the Eastern Amazon (Figure 1). The watershed has the largest multimineral deposits in the Amazon, as well as industrial exploitation of iron, manganese, copper and nickel ores in conservation units and artisanal mining (gold, precious stones, etc.) in areas outside the UCs (Souza Filho et al., 2021). Approximately one-third of the basin is within protected areas (conservation units and indigenous land), which indicates the environmental importance of the region for biodiversity protection. The deforested areas (approximately half of the watershed area) are mostly used for pastures, and the IRB region is responsible for approximately $35 \%$ of the cattle herding in the state of Pará (Instituto Brasileiro de Geografia e Estatística, 2017). According to Silva Júnior et al. (2017), the assets produced in the BHRI correspond to $25 \%$ of the GDP of the state of Pará.

The Itacaiúnas River is approximately $520 \mathrm{~km}$ long, with an altimetric range of $370 \mathrm{~m}$ and a low gradient of $0.7 \%$ (Figure 1). In general, the drainage patterns are dendritic, meandering, and entrenched; the river exhibits marked geological control and many 


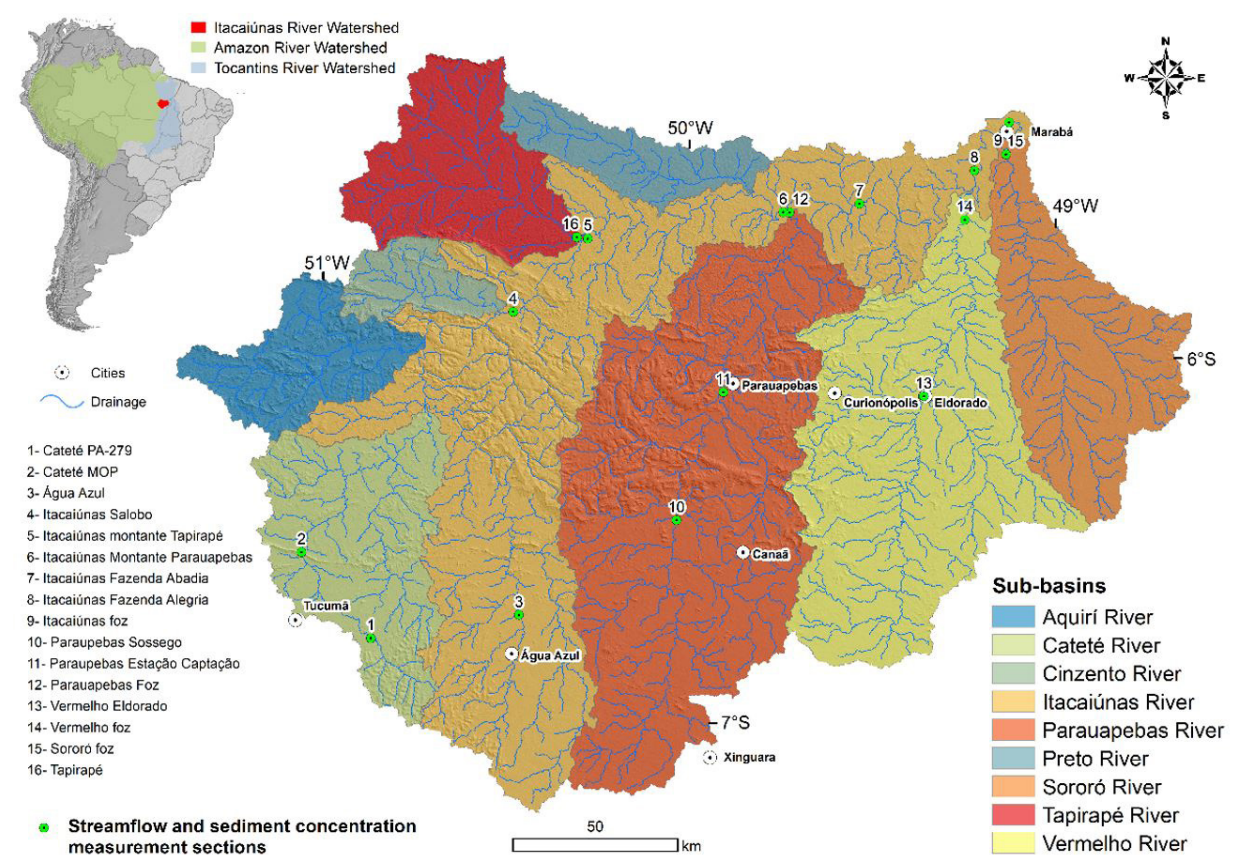

Figure 1. Itacaiúnas River Watershed and its main tributaries and the locations of the hydrosedimentological monitoring sections.

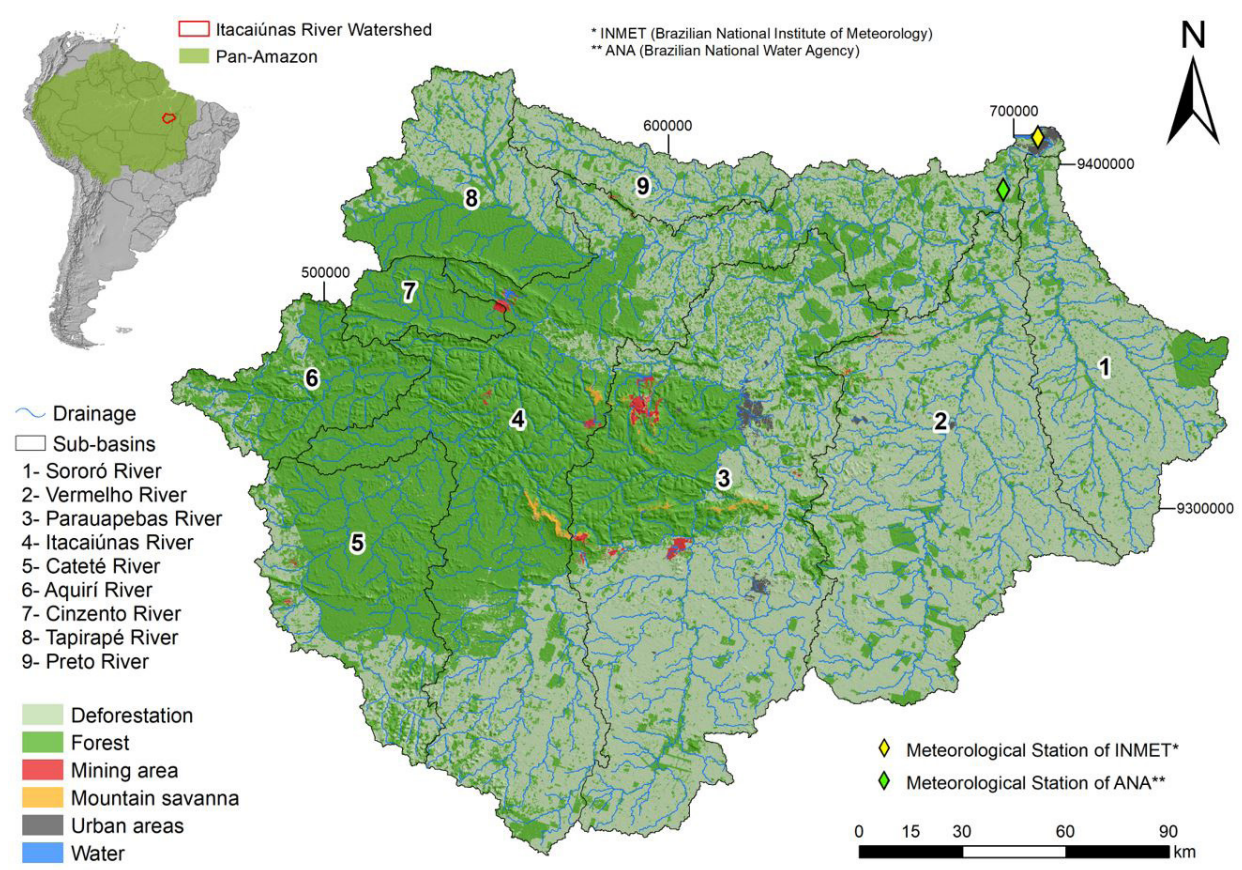

Figure 2. Itacaiúnas River Watershed land use and land cover map (Modified from Nunes et al., 2019).

rapids and has a predominantly rocky bottom with pebble and gravel midchannel alluvial deposits, as well as sandy point bars.

Recent studies conducted in the region defined five main types of land use and land cover (Souza Filho et al. 2015, 2016, 2018; Zappi, 2017; Nunes et al., 2019): tropical forest (dense rainforest) and metallophile savanna dominate the untouched landscape and account for $\sim 48 \%$ of the area, which is primarily concentrated in conservation units and indigenous lands; vast grasslands for cattle raising (deforested areas) currently occupy much of the landscape $(\sim 51 \%)$, whereas urban areas and open pit mining regions occupy restricted areas (Figure 2).

The Carajás Mountains are located in the central-west region of the IRW, with elevations ranging from 350 to $900 \mathrm{~m}$. In the region adjacent to the plateau, the elevation of the terrain ranges from 80 to $300 \mathrm{~m}$.

The climate of the region is defined as a tropical monsoon (Am) climate with two main seasons, a rainy season (November to May), which has a mean rainfall of $1,550 \mathrm{~mm}$, and a dry season (June 
to October), which has a mean rainfall of $350 \mathrm{~mm}$. The recorded mean air temperature is $27.2{ }^{\circ} \mathrm{C}$, and the relative air humidity is approximately 80\% (Moraes et al., 2005; Alvares et al., 2013).

The soils in the watershed, according to the Empresa Brasileira de Pesquisa Agropecuária (2006) classification, are predominantly red-yellow Argisol (66\%), Red-Yellow Latosol (22\%), Lithic Neosol (11\%), and Quartzarenic Neosol (1\%).

In the north, the geology of the IRW includes the Bacaja domain, which is composed of high-grade metamorphic rocks and metavolcanic and metasedimentary rocks. The province of Carajás and the southern part of the basin are occupied by the Archean Rio Maria, Sapucaia and Canaã dos Carajás domains, which consist of granitoid rocks with diverse compositions and subordinate metamorphic-ultramafic greenstone belts. The eastern portion of the BHRI is represented by the Araguaia Belt, which contains sedimentary, metasedimentary, and mafic-ultramafic rocks and quaternary deposits and lateritic coverings (Dall'Agnol et al., 2017; Feio et al., 2013; Monteiro et al., 2008; Sousa et al., 2015, Sahoo et al., 2019).

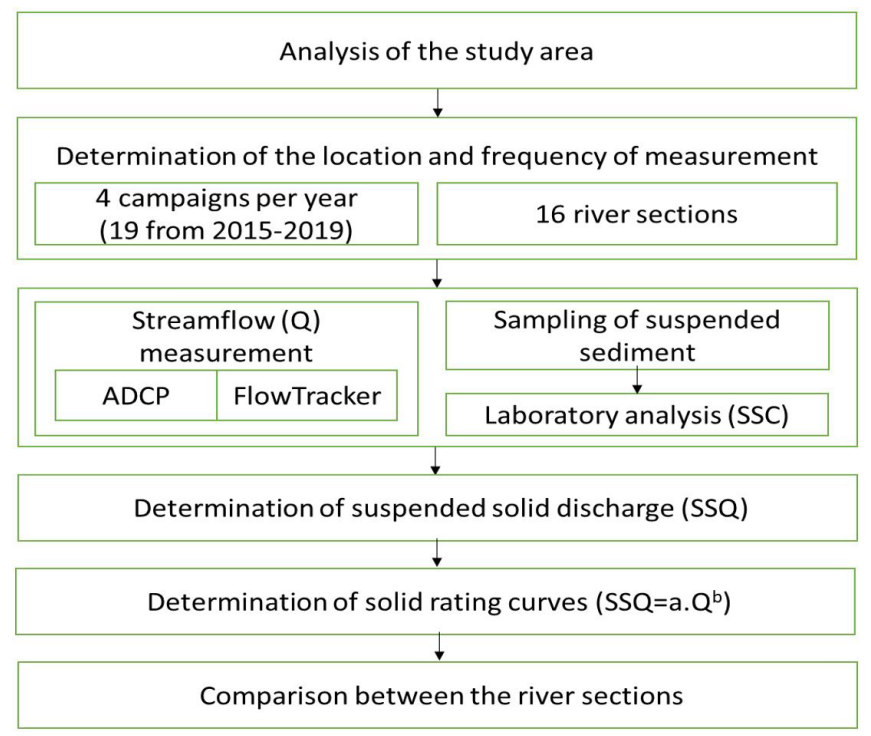

Figure 3. Flowchart of the methods.

\section{Hydrosedimentological monitoring}

Figure 3 shows the flowchart of the activities performed during this work. The data necessary for performing this study were collected in field campaigns of seasonal hydrosedimentological monitoring conducted as part of the Itacaiúnas Project of the Vale Institute of Technology (Instituto Tecnológico Vale - ITV). The monitoring included four annual campaigns from March 2015 to October 2019, totaling 19 campaigns. During each campaign, water level and liquid discharge (streamflow) measurements were taken, and the waters were sampled to calculate the suspended sediments at each station.

The annual number of campaigns was determined by the seasonal variation in streamflow and the cost of the campaigns. The time period of each streamflow measurement campaign was planned and defined based on historical streamflow data from the Fazenda Alegria station of the National Water Agency (Agência Nacional de Águas e Saneamento Básico, 2021) and rainfall data from the Marabá station of the National Meteorological Institute (Instituto Nacional de Meteorologia, 2021) (Figure 2). The monthly values for the analyzed period are presented in Figure 4. From July to November, the long-term mean streamflow is below $20 \mathrm{~mm}$.month ${ }^{-1}$, while the average monthly peak is approximately $100 \mathrm{~mm}$.month ${ }^{-1}$ in March (Cavalcante et al., 2019). To represent the seasonal behavior of the IRW, the campaigns were preferably undertaken in the months of maximum (March/April), minimum (September), and intermediate streamflows (falling streamflow in June and rising water in January).

The 16 control sections for hydrosedimentological monitoring in the IRW were chosen based on access to these sections and on their distinct environmental features (altitude, slope, geology, soils, land cover, and intensity of anthropogenic influence) so that the fluvial dynamics of the watershed could be fully represented. The 16 hydrosedimentological monitoring sections were distributed as follows: seven were allocated along the Itacaiúnas River, three along the Parauapebas River, two along the Vermelho River, two along the Cateté River, one along the Sororó River, and one along the Tapirapé River (Figure 1).

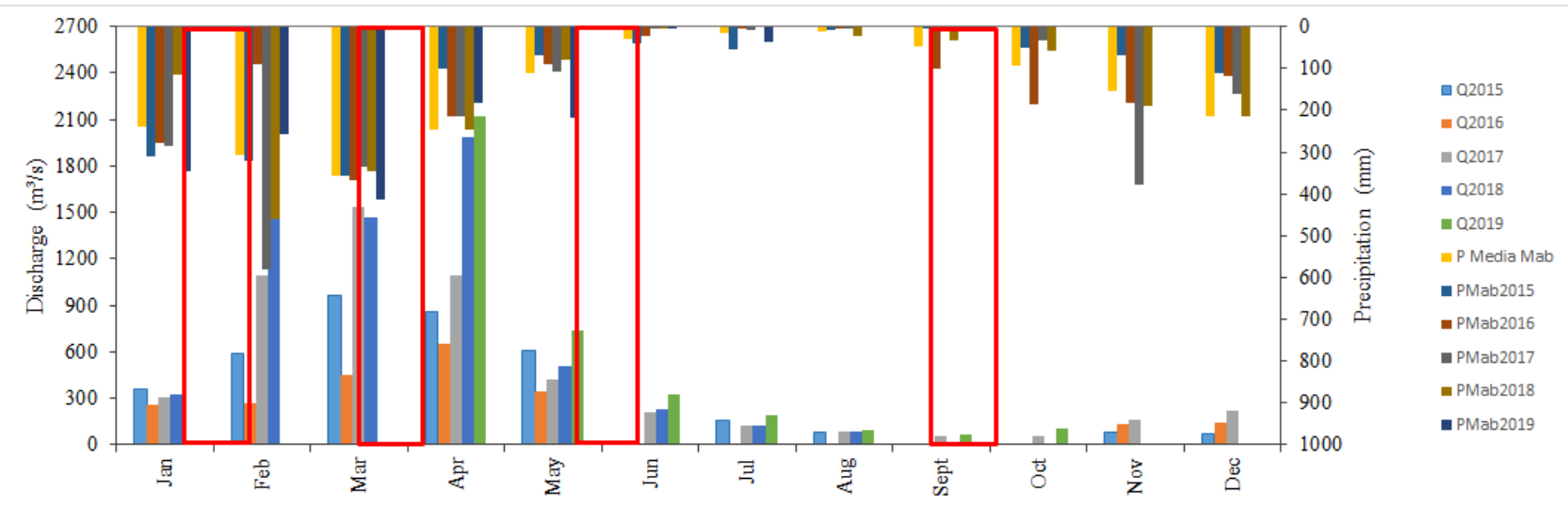

Figure 4. Monthly streamflow (Fazenda Alegria, ANA) and rainfall (Marabá, INMET) data from January 2015 to December 2019 in the Itacaiúnas River Watershed and the time periods of the campaigns shown by the red boxes. 


\section{Liquid discharge (streamflow) measurements}

The methods adopted in the field campaigns for streamflow measurement followed the international standards and regulations recommended in the ANA and CPRM manual of best practices for the use of acoustic Doppler current profilers (ADCPs).

Two acoustic methods were used to measure streamflow depending on the seasonal variation in the river water levels.
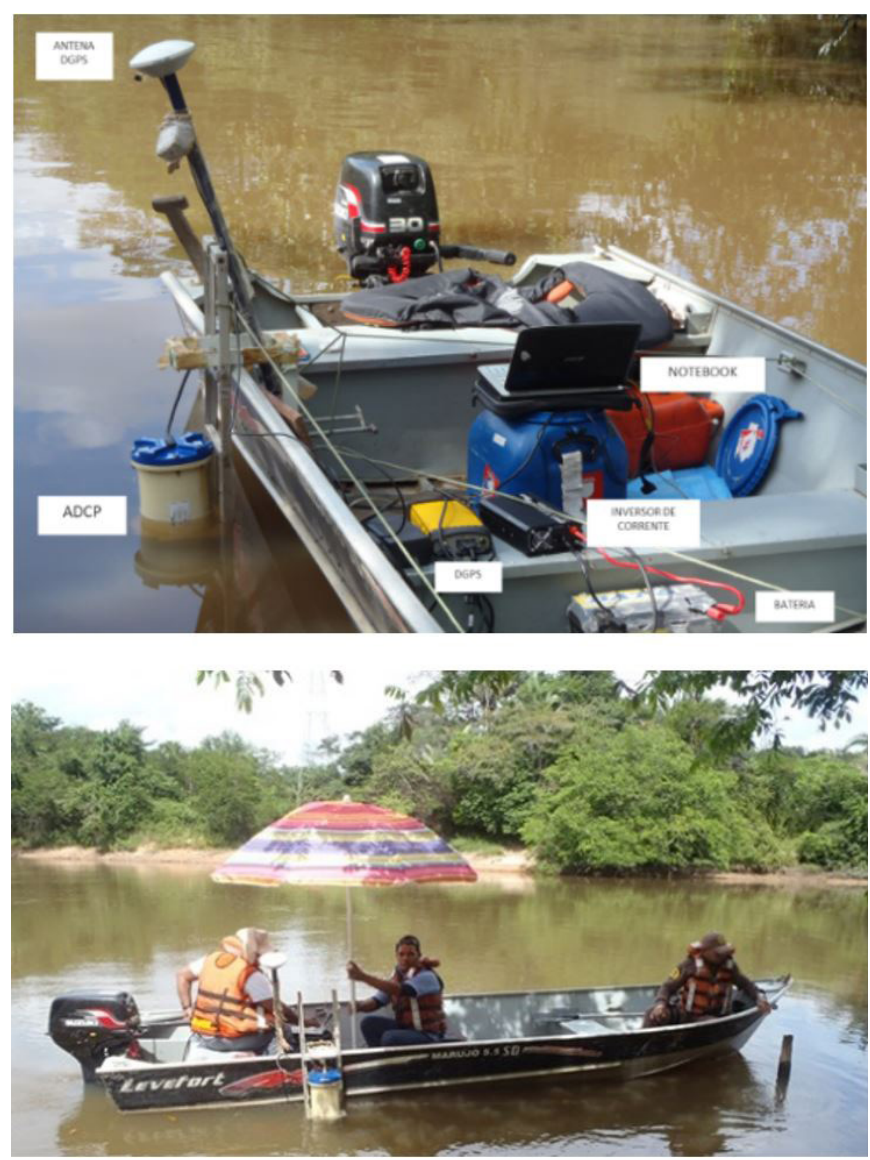

Figure 5. Equipment and vessels used in flow measurements in the rivers within the Itacaiúnas River basin.
In the first method, streamflow was measured from a moving boat (Figure 5) using the Teledyne 600 and $1200 \mathrm{MHz}$ and SonTek M9 ADCPs, whose data were acquired and processed using the WinRiver II and RiverSurveyor software programs, respectively (RD Instruments, 2013; Sontek, 2018). In this method, the calculation of the effective streamflow of each fluvial measurement section requires taking at least two pairs of measurements (two outbound and two inbound) to calculate a mean, which is the streamflow value of each measurement section. In addition to streamflow measurements of the sections, moving-bed tests were also performed using two methods: anchored boat and looping. These tests are important to assess whether this parameter has any effect on the calculated streamflow value.

The second method used the acoustic Doppler velocimeters SonTek FlowTracker I and II, which are designed to take measurements in narrow channels with water depths of less than $120 \mathrm{~cm}$, as occurs during the dry seasons (Figure 6). This method uses the "mid-section" measurement, in which the velocity is measured in each vertical direction at $60 \%$ or at $20-80 \%$ depth in each subsection (Santos et al., 2001). Last, the measurements were integrated automatically, and the total streamflow was calculated for the section, generating a report with all the data from the section using SonTek FlowTracker software v.2.3.

\section{Sample collection and calculation of suspended sediment concentration}

In conjunction with the streamflow measurements, suspended sediment samples were collected using the direct method (instantaneous spot sampling) to determine the SSC. A single sampling was performed near the water surface in the main river channel ( $100 \mathrm{~cm}$ depth), and 2-3 L of water was collected using a Van Dorn bottle, of which $1000 \mathrm{~mL}$ was split evenly into two 500-mL plastic bottles; these bottles were stored in a plastic box for transport and were sent for processing at the Laboratory of the Environmental Geology and Water Resources Group of ITV.

The laboratory tests (Figure 7) consisted of determining the SSC according to the method described by Wetzel \& Likens (1991) and Carvalho et al. (2000). The collected water samples

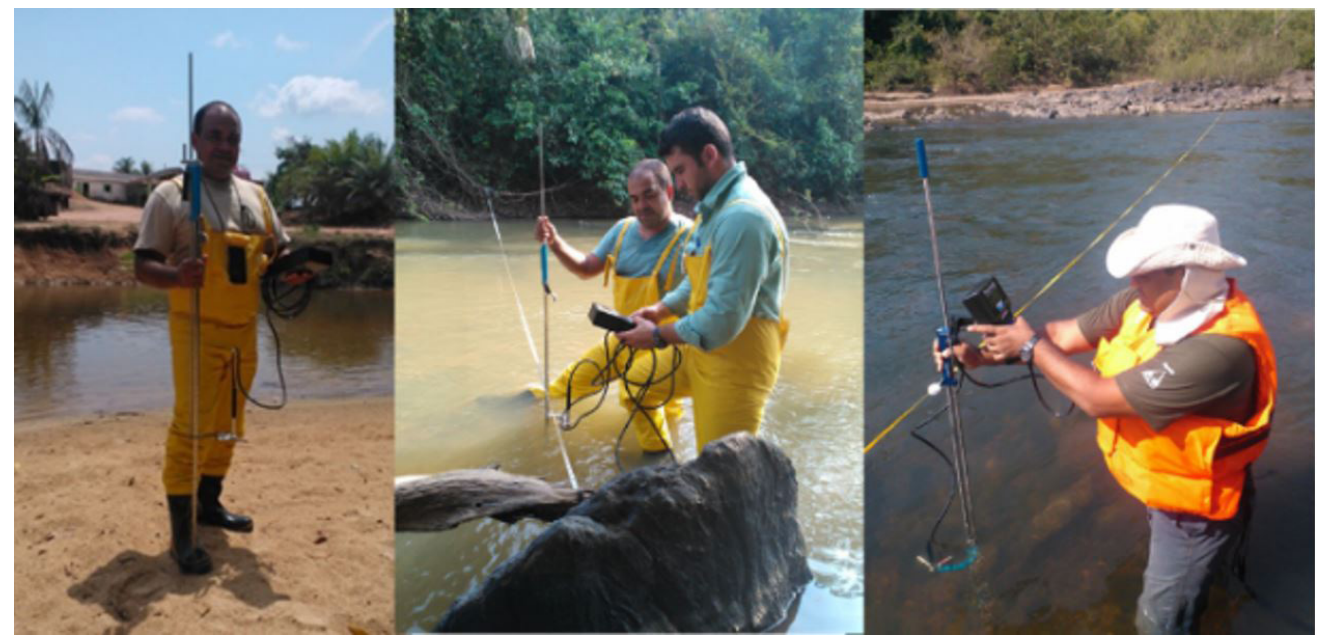

Figure 6. Photos of flow measurement with FlowTracker. 


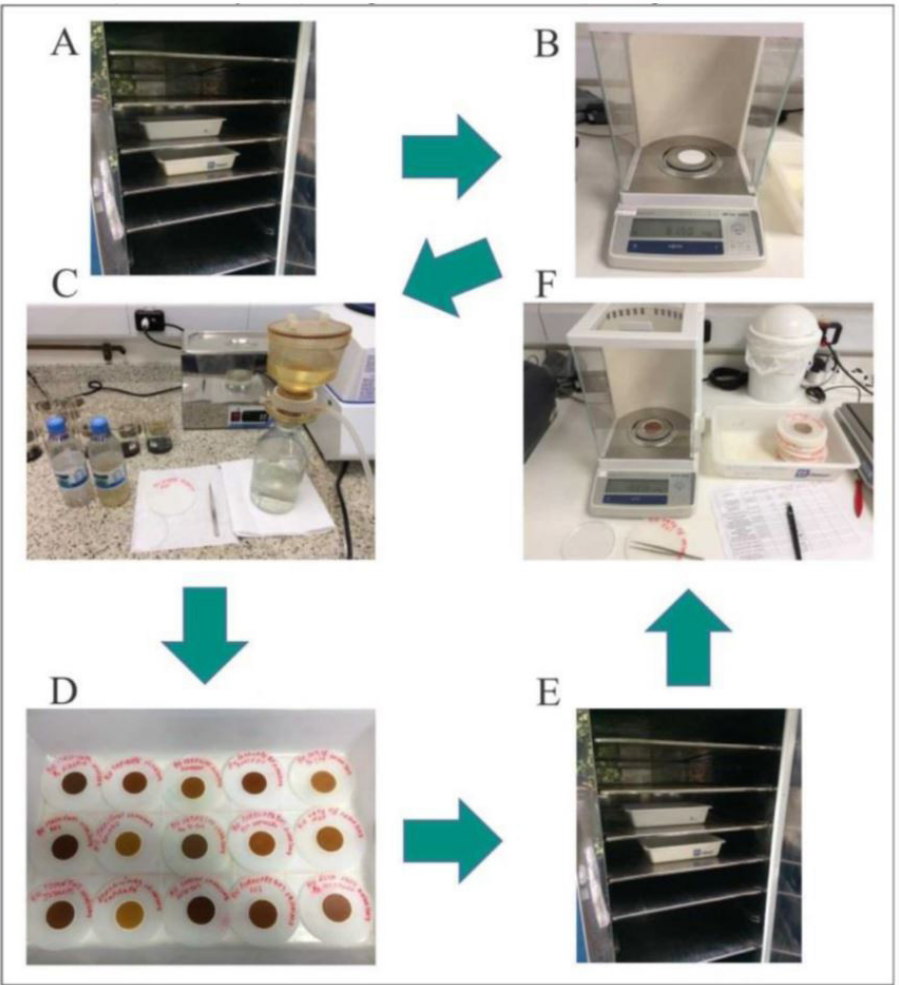

Figure 7. Stages of laboratory analysis. (A) Drying the filters; (B) Weighing the dry filters; (C) Filtering the samples; (D) Identification; (E) Drying the samples; (F) Weighing the dry samples (Adapted from Pina Neto et al., 2020).

were filtered using a water suction pump with a $0.45-\mu \mathrm{m}$ cellulose membrane filter that was $47 \mathrm{~mm}$ in diameter. The filters were dried and weighed before and after filtration, and the difference in weight was divided by the filtered volume to calculate the SSC.

\section{Solid discharge and specific sediment yield}

To calculate the suspended sediment discharge, we assumed that suspended sediments would flow at the same velocity as the current throughout the cross-section; thus, their discharge would equal the product of the streamflow and the mean concentration. Thus,

$\mathrm{SSQ}=0.0864 \times \mathrm{Q} \times \mathrm{SSC}$

where

SSQ is the solid discharge or estimated suspended sediment flow (tons/day);

$\mathrm{Q}$ is the measured instantaneous streamflow $\left(\mathrm{m}^{3} / \mathrm{s}\right)$;

and SSC is the estimated instantaneous solids or suspended sediment concentration $(\mathrm{mg} / \mathrm{L})$.

The specific suspended sediment yield (SSY) per unit area was determined by:

$\mathrm{SSY}=\left(\frac{\mathrm{SSQ}}{\mathrm{A}}\right) * 1000$

where

SSY - the specific sediment yield $\left(\mathrm{kg} / \mathrm{day} / \mathrm{km}^{2}\right)$;

SSQ - the estimated suspended sediment discharge (tons/day); and $\mathrm{A}$ - the contributing watershed area $\left(\mathrm{km}^{2}\right)$.

\section{Sediment rating curves}

The sediment rating curve of each monitoring section was defined using the power function:

$\mathrm{SSQ}=\mathrm{aQ}^{b}$

where SSQ is the estimated suspended sediment discharge (tons/day); $\mathrm{Q}$ is the measured streamflow $\left(\mathrm{m}^{3} / \mathrm{s}\right)$ associated with the SSC; and $\mathrm{a}$ and $\mathrm{b}$ are the constant and exponent, respectively, of the estimation ratio between specific suspended sediments for each period and the monitoring cross-section.

The power equation was used for the construction of sediment estimation curves, as it is the first and most commonly used equation in most studies (e.g., Phillips et al., 1999; Glysson, 1987; Asselman, 2000).

According to Asselman (2000), the power equation covers both the effect of increasing the current power at a higher discharge and the extent to which new sources of sediment become available in climatic conditions that cause high discharge.

The sediment rating curves were plotted in log-normal space to analyze changes in the curves and their trends. For each season, in each measurement section, the coefficient of determination $\left(\mathrm{R}^{2}\right)$ was calculated for streamflow and suspended sediment discharge data. The coefficient of determination indicates the degree of correlation between sediment concentration/suspended sediment discharge and streamflow. $\mathrm{R}^{2}$ ranges from 0 to 1 , and the higher 
the $\mathrm{R}^{2}$ is, the higher the correlation between the sample data is (Mendonça et al., 2019).

The curves were constructed and analyzed in two ways: with data from the rainy season (November to April) and dry season (June to September) plotted in different curves and with one curve integrating the data from both seasons.

\section{RESULTS}

The results of streamflow, suspended sediment concentration and discharge and the sediment rating curves are first presented by subbasins (main tributaries of the Itacaiúnas River) and discussed considering the land use and other characteristics of each area. Then, the results are compared to provide an analysis of the entire IRW. Table 1 summarizes the average values measured during the 5 years of hydrosedimentological monitoring in the 16 control sections, the percentages of deforested areas and forests, as well as the determination coefficients $\mathrm{R}^{2}$ and the constants and exponents ( $\mathrm{a}$ and $\mathrm{b}$ ) obtained in the power equation, which is discussed below. We used the modified nonparametric Mann-Kendall test (Mann, 1945; Kendall, 1975; Hamed \& Rao, 1998) to investigate the statistical significance (with the confidence threshold set at the 0.05 level) for the five-year (2015-2019) time series of Q and the SSC of all hydrosedimentological stations. The null hypothesis in the Mann-Kendall test is that the data are independent and randomly ordered. The only statistically significant trend was that of the Q time series for the Cateté River.

\section{Cateté River}

The Cateté River, which has a basin of $3600 \mathrm{~km}^{2}$ located in the southwestern sector of the IRW (Figure 1), is an important tributary of the left bank and of the most upstream section of the Itacaiúnas River. This subbasin crosses the municipalities of Tucumã and Ourilândia do Norte and the Xikrin indigenous land; it is $142 \mathrm{~km}$ long and has a $292 \mathrm{~m}$ difference in elevation.

This subbasin has two monitoring sections, the Cateté River/PA-279 and the Cateté River/MOP sections, which drain areas of 376.29 and $897.87 \mathrm{~km}^{2}$, respectively, accounting for $25 \%$ of the total area (Table 1). The analyzed sections of the Cateté River basin represent its most upstream areas.

The boxplot in Figure 8A shows the variation in sediment concentrations in different seasons and monitored sections. The outliers (SSC > $60 \mathrm{mg} / \mathrm{L}$ ), which were observed in both sections, increased the mean sediment concentration of the rainy season from 22.06 to $25.14 \mathrm{mg} / \mathrm{L}$ in the PA-279 section and from 26.65 to $30.62 \mathrm{mg} / \mathrm{L}$ in the MOP section. The sediment concentration increased from upstream to downstream.

In Figure 8B, the mean streamflow values of 3.2 and $3.8 \mathrm{~m}^{3} / \mathrm{s}$ were similar between the dry seasons, highlighting that no significant reload occurred between sections. In the rainy season, the mean input to the MOP section, at $25.1 \mathrm{~m}^{3} / \mathrm{s}$, was $35 \%$ greater than that to the PA-279 section, at $17.1 \mathrm{~m}^{3} / \mathrm{s}$. The streamflow values of approximately $15 \mathrm{~m}^{3} / \mathrm{s}$ in section PA-279 and $21 \mathrm{~m}^{3} / \mathrm{s}$ in section MOP, which had high sediment discharge values $(>100 \mathrm{mg} / \mathrm{L})$ in

Table 1. Location, drainage area, and seasonal average (SSC - suspended sediment concentration, Q - Liquid discharge, SSQ - suspended sediment discharge and SSY - specific sediment yield) of various locations along the Itacaiúnas River and its tributaries, as well as the determination coefficients $\mathrm{R}^{2}$ and the constants and exponents ( $\mathrm{a}$ and $\mathrm{b}$ ) of the power function.

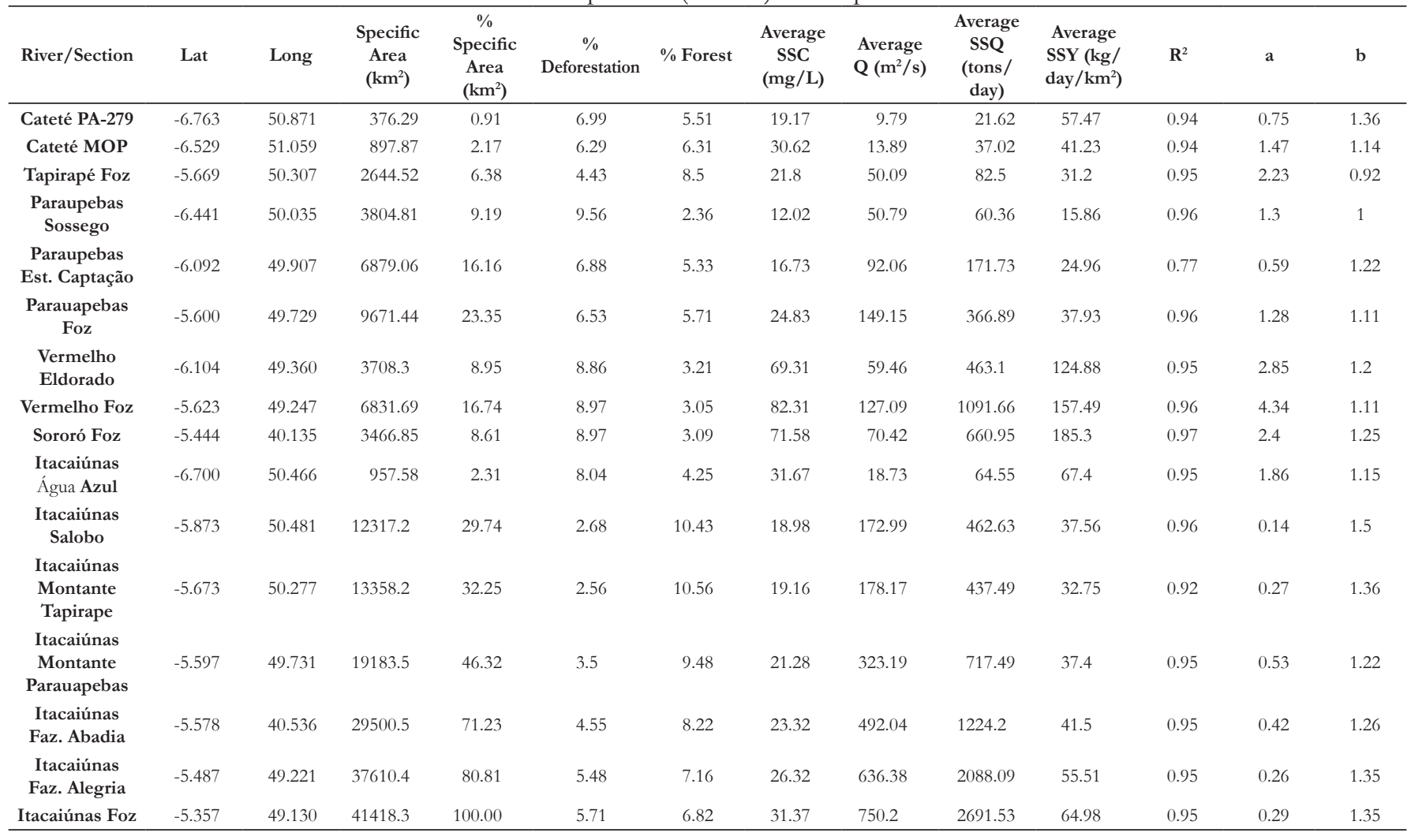



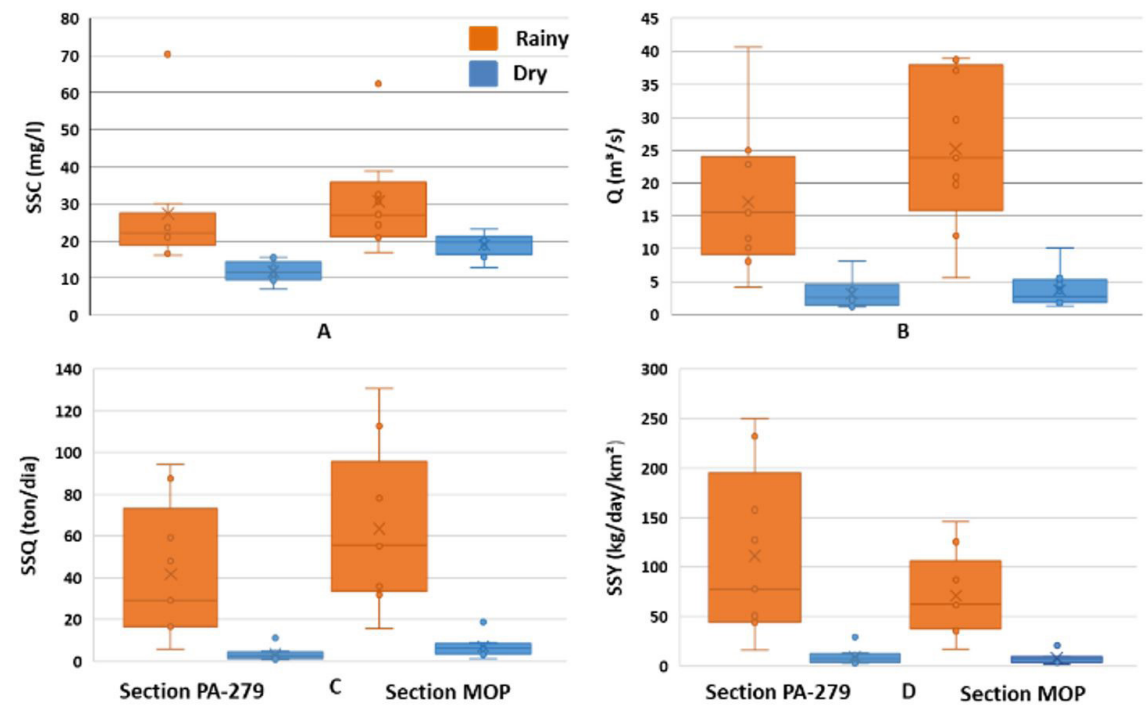

Figure 8. Boxplot of suspended sediment concentration - SSC, (A), streamflow - Q (B), suspended sediment discharge - SSQ (C), and specific sediment yield - SSY (D) in different seasons in the monitoring sections of the Catete River.

January 2019, may reflect the intense rainfall that occurred during that season in the watershed.

Figure 8C shows the estimated suspended sediment discharges for both sections, highlighting that during the dry season, sediment transport was low, averaging 3.47 tons/day at PA-279 and 7.14 tons/day at MOP. The rainy season showed higher values, reflecting increases in streamflows and concentrations that averaged 41.79 tons/day at PA-279 and 63.38 tons/day at MOP.

The mean specific sediment yield was 111.06 and $70.81 \mathrm{~kg} /$ day $/ \mathrm{km}^{2}$ in the rainy season and 9.23 and $7.95 \mathrm{~kg} / \mathrm{day} / \mathrm{km}^{2}$ in the dry season in the PA-279 and MOP sections, respectively (Figure 8D).

The separation between the dry and rainy seasons did not improve the accuracy of the sediment rating curve for this subbasin. For the dry season, the fitted curves presented $\mathrm{R}^{2}$ values $>0.91$, while for the rainy season, they presented $R^{2}$ values $>0.67$, indicating lower data dispersion in the dry season (Figure 9A). The suspended sediment rating curves with the data of both seasons had coefficients of determination of 0.94 for both river sections (Figure 9B). The curves show that sediment discharges tended to stabilize with increased streamflow, probably due to the depletion of sediment availability.

\section{Tapirapé River}

The Tapirapé River drains the northwestern sector of the IRW; it has an area of approximately $2700 \mathrm{~km}^{2}$, is $81.3 \mathrm{~km}$ in length, has a $142 \mathrm{~m}$ difference in elevation, and $62 \%$ of its area is preserved within the conservation unit known as the TapirapéAquiri Biological Reserve. The river section is situated near the mouth of the river.

The streamflow averaged $100.89 \mathrm{~m}^{3} / \mathrm{s}$ in the rainy season and $9.44 \mathrm{~m}^{3} / \mathrm{s}$ in the dry season, clearly indicating seasonality (Figure 10B, Table 1). A low value corresponding to February 2016 was noted in the rainy season. Despite the large difference in streamflow, the average SSC was similar between the two periods (Figure 10A). The mean SSQ was 163.95 tons/day in the rainy season and 17.34 tons/day in the dry season (Figure 10C), and the mean values of SSY were 62 and $6.36 \mathrm{~kg} / \mathrm{day} / \mathrm{km}^{2}$ (Figure 10D), respectively. A very high value of 362 tons/day was observed in February 2017 (Figure 10C).

The seasonal sediment rating curves of the Tapirapé River show a behavior compatible with its relatively small drainage area and a unique environmental context because it drains, on its right bank, a preserved area with untouched forest cover, whereas its left bank is an area covered by pasture. The sediment rating curve presented the following values: $\mathrm{R}^{2}=0.96$ for the dry season, $\mathrm{R}^{2}=0.59$ for the rainy season, and $\mathrm{R}^{2}=0.95$ for all seasons (Figure 11). These results reflect variations in suspended sediment discharges for streamflows greater than $90 \mathrm{~m}^{3} / \mathrm{s}$, which may be due to a variation in the rainfall intensities and variable sediment inputs or the low accuracy of streamflow and suspended sediment concentration estimation measurements for higher streamflows.

\section{Parauapebas River}

The Parauapebas River subbasin is located in the central region of the IRW and spans an area of $9,600 \mathrm{~km}^{2}$. The Parauapebas River is approximately $270 \mathrm{~km}$ long and primarily drains in the south-north direction; it has three hydrosedimentological monitoring sections (Figure 1). The Sossego section covers the upper Parauapebas River sector and is characterized by an intermittent water regime. The city of Canaã dos Carajás and the Sossego Copper Mine, which are supplied and drained by its waters, are in this sector. The Estação de Captação section encompasses the middle stretch of the subbasin, where the river partly intersects the Carajás Mountains, with altitudes of approximately 700 meters and with a preserved area along its left bank. The iron mines of the Northern Carajás Mountains are nearby in the highest sectors and are surrounded by a preserved forest (Souza Filho et al., 2021), 

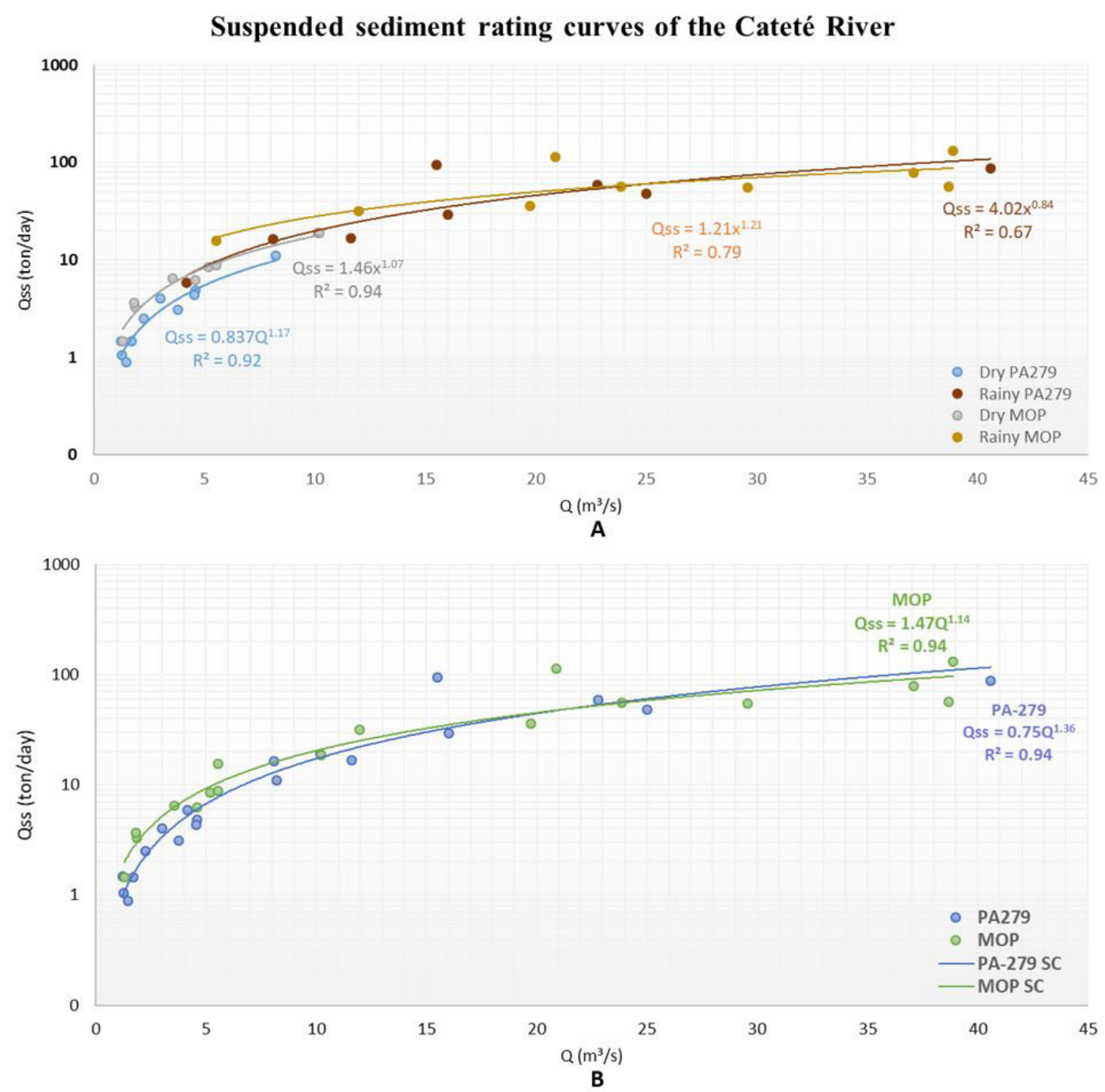

Figure 9. Suspended sediment rating curves for the Cateté River: dry and rainy season curves are shown together in (A), and the curves with all the data and their respective regression equations and coefficients of determination are shown in (B).

as is one of the largest cities of the southeastern region of Pará, Parauapebas. The third section (Foz) is located at the mouth of the subbasin and thus incorporates additional effects of the lower sector of the basin, which is dominated by extensive pastures, into its hydrosedimentological data (Figure 2).

Figure 12A shows a large variation in sediment concentration values in the Sossego section because the river was intermittent in four of the five monitoring years; the section lacked streamflow in the dry season and therefore sediment transport. By considering only periods with sediment transport in the dry season, the seasonal (dry and rainy) means were almost equal, with a difference of less than $2 \%$. This indicates that after surface runoff, the mean sediment transport in the Sossego section remained virtually unchanged throughout the year, in contrast to the streamflows.

The mean SSC and Q and, consequently, the mean SSQ, increased from upstream to downstream (Figure 12A, B and C) (Table 1). The mean SSY also increased with increasing catchment area. The SSY ranged from 31.94 and $1.4 \mathrm{~kg} / \mathrm{day} / \mathrm{km}^{2}$ in the Sossego section to 79.07 and $5.03 \mathrm{~kg} / \mathrm{day} / \mathrm{km}^{2}$ in its mouth (FOz) in different seasons, which was an increase in suspended sediment yield of approximately 60\% during the rainy season and of $70 \%$ during the dry season between the upper and lower Parauapebas River.

Figure 13 illustrates the sediment rating curves of the dry (A) and rainy (B) seasons and integrated periods (C) for each monitoring section. When constructing the sediment rating curve of the Sossego section for the dry season, the periods when the river was completely dry were disregarded because 0 values are not accepted in the regression equation that was used. The sediment rating curve of this section had a high coefficient of determination $\left(\mathrm{R}^{2}=0.99\right)$ and the lowest discharge values among the sections. The lowest $\mathrm{R}^{2}$ value was obtained for the Parauapebas River mouth (Foz) section using only the values for the rainy season $\left(\mathrm{R}^{2}=0.77\right)$.

\section{Vermelho River}

The Vermelho River subbasin, which runs through the centraleastern sector of the IRW, has an area of approximately $7,000 \mathrm{~km}^{2}$, is $160 \mathrm{~km}$ in length and is monitored by two hydrosedimentological 

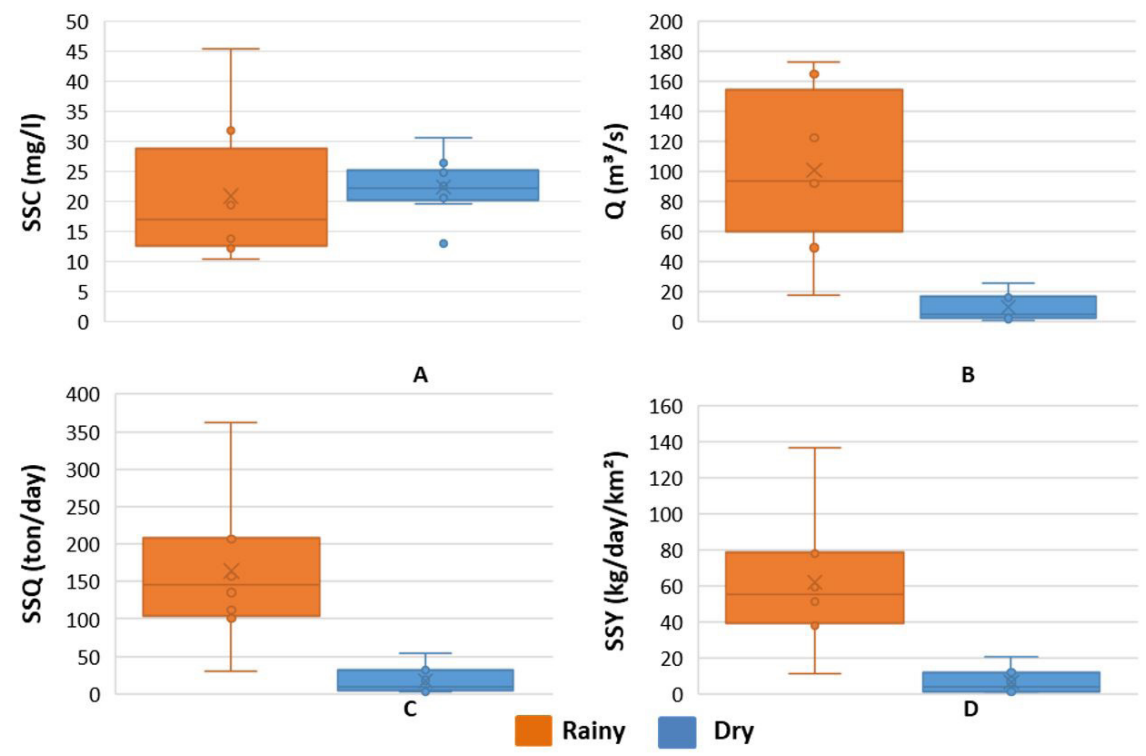

Figure 10. Boxplots of suspended sediment concentration (A), streamflow (B), suspended sediment discharge (C), and specific sediment yield (D) in different seasons along the Tapirapé River monitoring sections.

\section{Suspended sediment rating curves of the Tapirapé River}

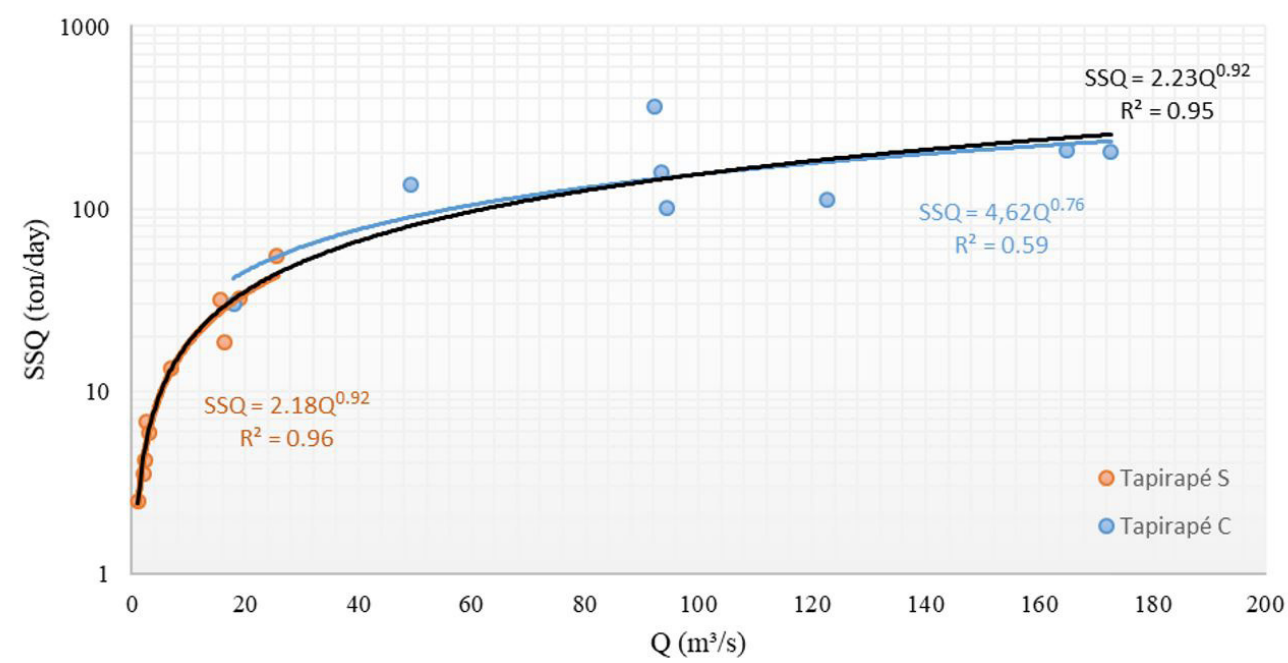

Figure 11. Suspended sediment rating curves of the dry (D) and rainy (R) seasons and the integrated curve of the Tapirapé River for both the dry and rainy seasons (DR).

sections: one in the city of Eldorado dos Carajás, which drains an area of $3,700 \mathrm{~km}^{2}$, and the other in its mouth. More than $75 \%$ of the areas of both sections are deforested land that has been replaced by pasture. According to Salomão et al. (2018), throughout the Vermelho River valleys, the topographical relief is flat, with altitudes ranging mainly from 80 to $400 \mathrm{~m}$. The relief becomes rougher in the western sector, where mountainous terrains are associated with highly dissected plateaus, with altitudes ranging from 400 to $780 \mathrm{~m}$. In addition, the local elevations are related to mafic-ultramafic intrusions in the central lowlands and the sedimentary units of the Parnaíba sedimentary basin. These geological and geomorphological features of the Vermelho River subbasin directly affect its hydrosedimentological characteristics, as shown by its high suspended sediment discharges.
This subbasin had the second highest SSC in both seasons (Table 1), with similar means in the upstream and downstream sections during the rainy season (101.5 and $105.6 \mathrm{mg} / \mathrm{L}$ ) (Figure 14A). The outlier observed in the dry season in the Foz section resulted from the atypical rainfall recorded in September 2018. The Q and SSQ at the mouth of the river were approximately double those in the Eldorado section (Figure 14B and C). The SSY was the second highest of the entire basin (Figure 14D) (Table 1).

Figure 15 shows the seasonal and integrated sediment rating curves for the two monitoring sections. The dry season curves had high coefficients of determination for both the Eldorado section $\left(\mathrm{R}^{2}=0.92\right)$ and the Foz section $\left(\mathrm{R}^{2}=0.89\right)$. The rainy season curves, despite clearly showing a good fit, had lower coefficients of determination, with values of $R^{2}=0.77$ at 

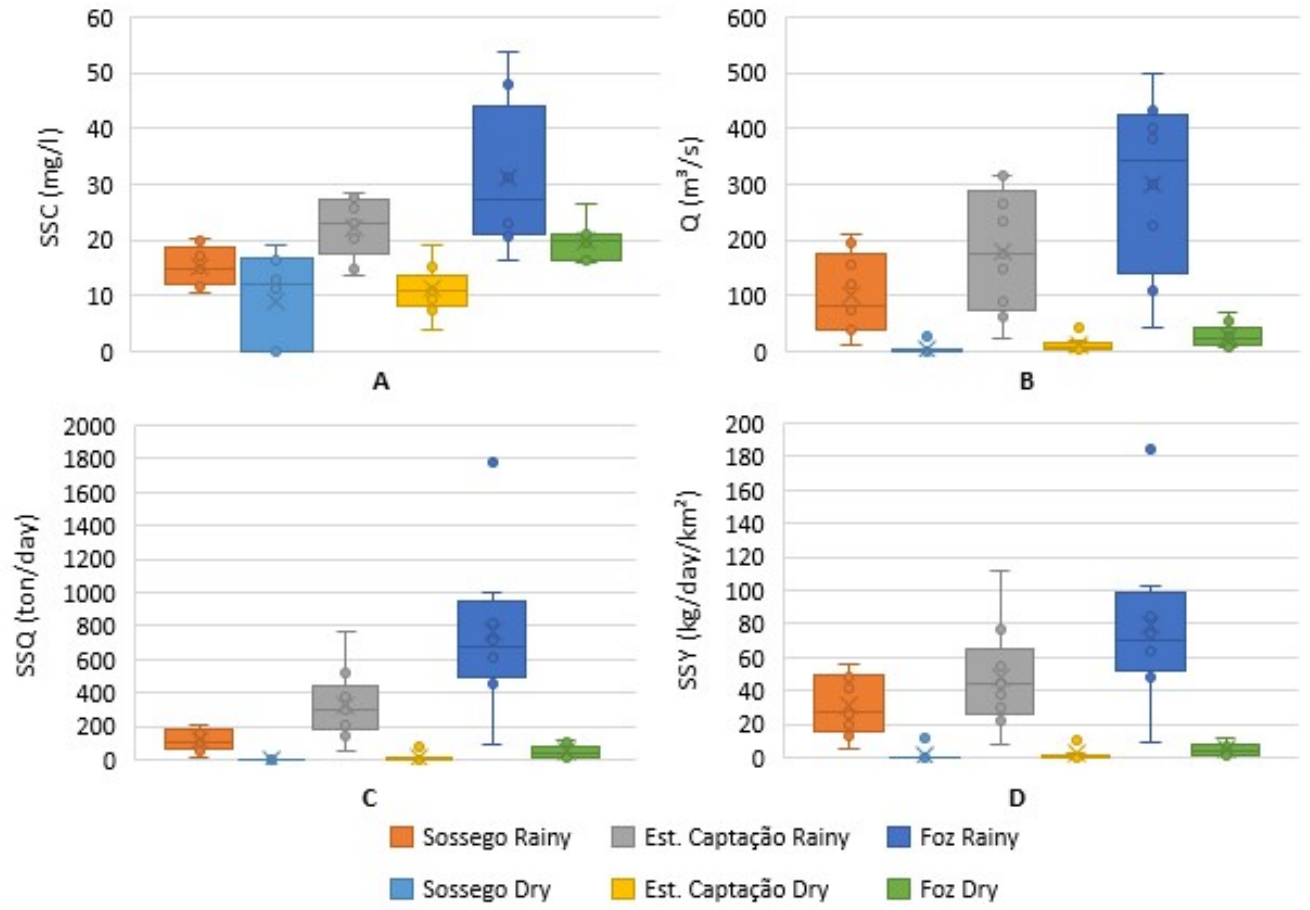

Figure 12. Boxplot of suspended sediment concentration (A), streamflow (B), suspended sediment discharge (C), and specific sediment yield (D) in different seasons along the monitoring sections of the Parauapebas River subbasin.

Eldorado and $\mathrm{R}^{2}=0.87$ at Foz. Figure $15 \mathrm{~B}$ shows the curves with combined data from both seasons, with coefficients of determination of 0.95 and 0.96 for the Eldorado and Foz sections, respectively. Once again, the integrated data showed better regression coefficients.

\section{Sororó River hydrosedimentology}

The Sororó River subbasin, with an area of approximately $3,600 \mathrm{~km}^{2}$ and a length of $137 \mathrm{~km}$, drains the easternmost sector of the IRW, and its hydrosedimentological control section is located in its mouth (Foz). It has two small indigenous lands whose forests are still preserved (Figure 2), although $77 \%$ of the basin area has been replaced by pasture and urban areas. It is dominated by sedimentary and metasedimentary rocks (phyllites, slates, and sandy and clayey sediments), which form the Araguaia Belt (Salomão et al., 2018); it has a relatively flat terrain with altitudes ranging from 80 to $400 \mathrm{~m}$ and a land cover dominated by pasture.

This station had the highest mean SSC and SSY for the rainy season observed in the IRW, with values of $110.36 \mathrm{mg} / \mathrm{L}$ and $383.85 \mathrm{~kg} /$ day $/ \mathrm{km}^{2}$, respectively (Figure 16).

The sediment rating curve of this subbasin (Figure 17) had a coefficient of determination of 0.98 for the dry season. The sediment rating curve of the rainy season was affected by two extreme values, one of low sediment discharge (20 tons/day) and a streamflow of $11 \mathrm{~m}^{3} / \mathrm{s}$ (recorded on February 22, 2016) and another of extreme streamflow $\left(252 \mathrm{~m}^{3} / \mathrm{s}\right.$ on April 10, 2019) and a lower sediment discharge ( 880.55 tons/day) than those associated with lower streamflows in the same season. This indicates that this event had a lower sediment concentration than events with lower streamflows, which may have resulted from a depletion of sediment sources. These values affected the fitting of the sediment rating curves, which was $\mathrm{R}^{2}=0.84$. The sediment rating curve with all sampled data had a better fit $\left(\mathrm{R}^{2}=0.97\right)$ to the data and a more coherent curve.

\section{Itacaiúnas River}

The Itacaiúnas River is the main river of the basin because of its length of $\sim 520 \mathrm{~km}$. It was monitored by seven control sections, Água Azul $\left(950 \mathrm{~km}^{2}\right)$, Salobo $\left(12,320 \mathrm{~km}^{2}\right)$, Montante Tapirapé $\left(13,360 \mathrm{~km}^{2}\right)$, Montante Parauapebas $\left(19,180 \mathrm{~km}^{2}\right)$, Fazenda Abadia $\left(29,500 \mathrm{~km}^{2}\right)$, Fazenda Alegria $\left(37,610 \mathrm{~km}^{2}\right)$, and Foz $\left(41,420 \mathrm{~km}^{2}\right.$ ) (Table 1), which made it possible to better characterize and understand its hydrosedimentological dynamics.

The most upstream section (Água Azul) showed a high SSC for a small drainage area $\left(960 \mathrm{~km}^{2}\right)$, followed by the Salobo section, which, despite the inputs from the Cateté, Cinzento, and Aquiri Rivers, had a lower concentration in both the rainy and dry seasons for a much larger drained area and remained unchanged up to the Fazenda Abadia (Fz Abadia) section; at which point, the SSC markedly increased with the contribution of sediment from the Vermelho and Sororó Rivers, reaching the mouth with mean concentrations of $53.08 \mathrm{mg} / \mathrm{L}$ in the rainy season and $14.01 \mathrm{mg} / \mathrm{L}$ in the dry season (Figure 18A).

The seasonal mean streamflows in the mouth of the Itacaiúnas River (Itacaiúnas Foz section) in the 5 years of measurement were $1,460.88 \mathrm{~m}^{3} / \mathrm{s}$ and $110.58 \mathrm{~m}^{3} / \mathrm{s}$ in the rainy and dry seasons, respectively, which represented a streamflow decrease of over 


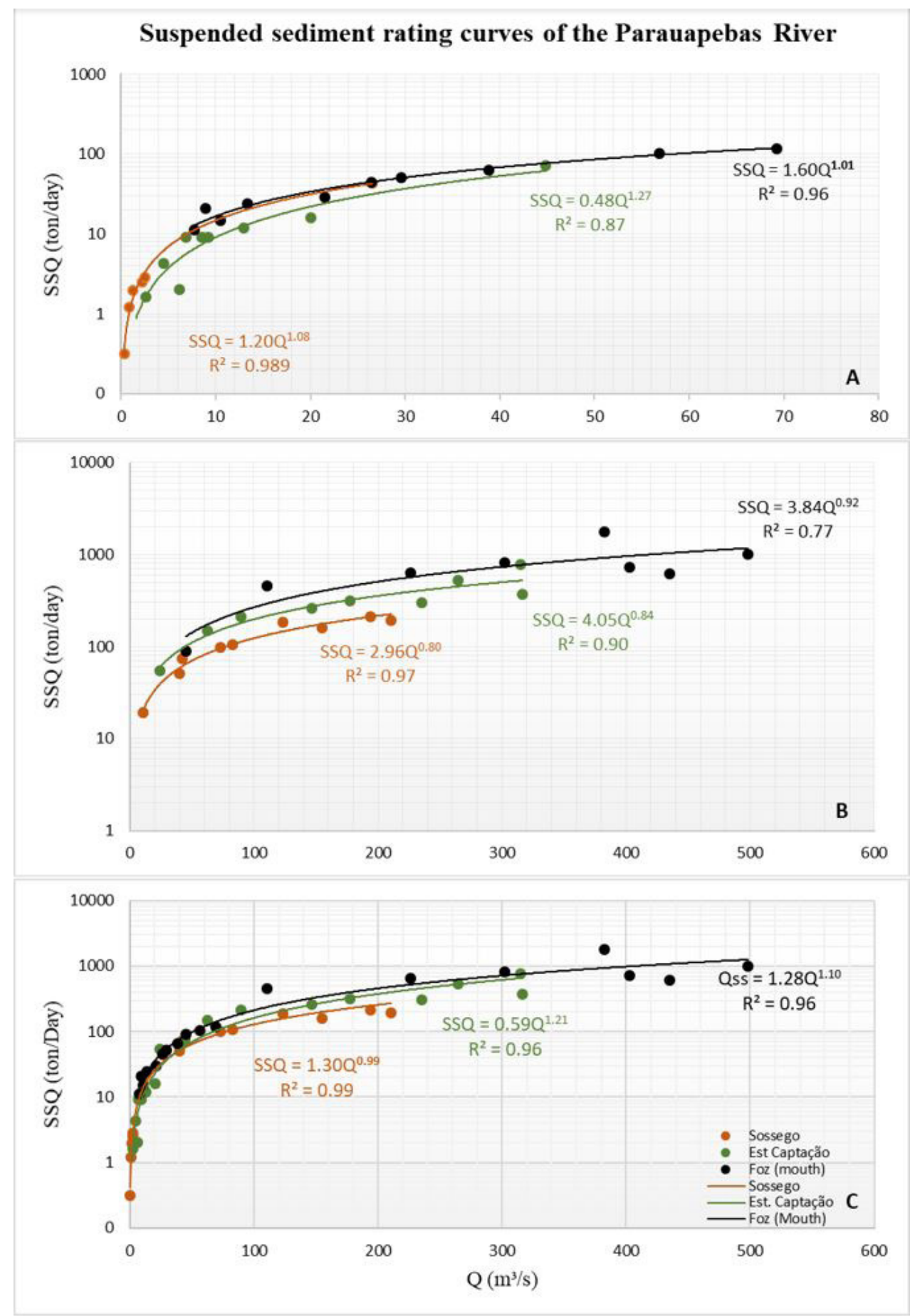

Figure 13. Sediment rating curves of the Parauapebas River.

$92 \%$ in the dry season (Figure 18B). The seasonal data collected in the Fazenda Alegria section showed a mean for the study period (5 years) of $636 \mathrm{~m}^{3} / \mathrm{s}$, which was close to the historical mean of $600 \mathrm{~m}^{3}$ /s (Silva Júnior et al., 2017).

Sediment discharges remained lower than 2,000 tons/day until the Montante Parauapebas section, and their means for the rainy season were similar in the stretch between the Salobo and Montante Tapirapé sections, highlighting an almost constant discharge (Figure 18C). After input from the Parauapebas River, the downstream sections showed a considerable increase in sediment discharges, reaching the mouth with 10,419 tons/day in the rainy season and 153 tons/day in the dry season. A low outlier, which was associated with low streamflows and concentrations, was identified at the beginning of the rainy season in 2016.

The boxplots of Figure 18D show the specific suspended sediment yield, indicating high yield in the upper Itacaiúnas River (Água Azul section). In April 2019, the Tapirapé Montante section showed the highest SSC in this area, as well as outliers of streamflow, suspended sediment discharge, and specific sediment yield, which reached $151.4 \mathrm{~kg} /$ day $/ \mathrm{km}^{2}$.

The low outliers identified early in the rainfall season of 2016 (February) are also distinctive. These outliers occurred in 

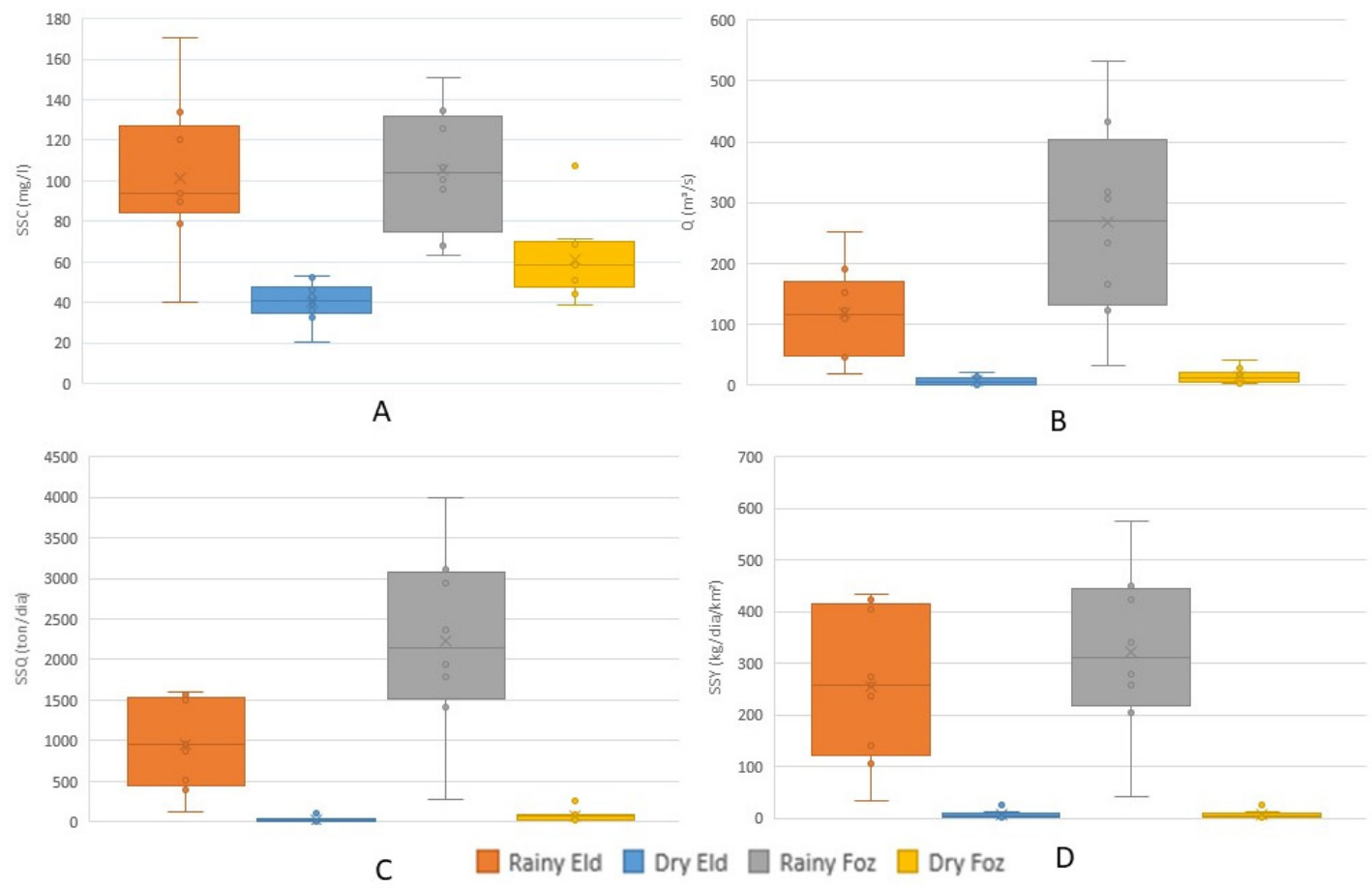

Figure 14. Boxplot of suspended sediment concentration (A), streamflow (B), suspended sediment discharge (C), and specific sediment yield (D) in different seasons along the monitoring sections of the Vermelho River subbasin.
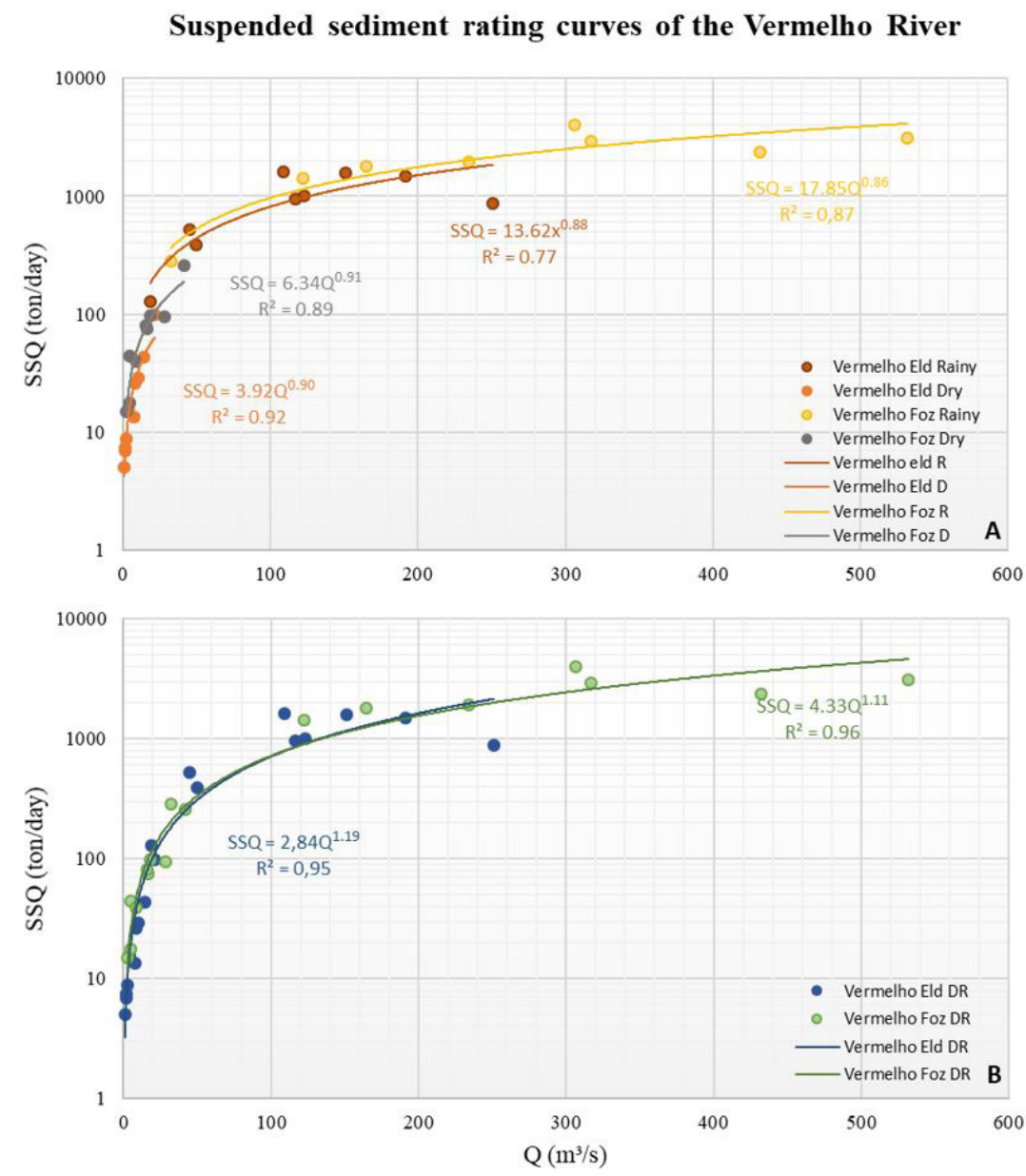

Figure 15. Suspended sediment rating curves as a function of streamflow in the Vermelho River for both monitoring sections (Eldorado dos Carajás and Foz) and their respective regression equations. 

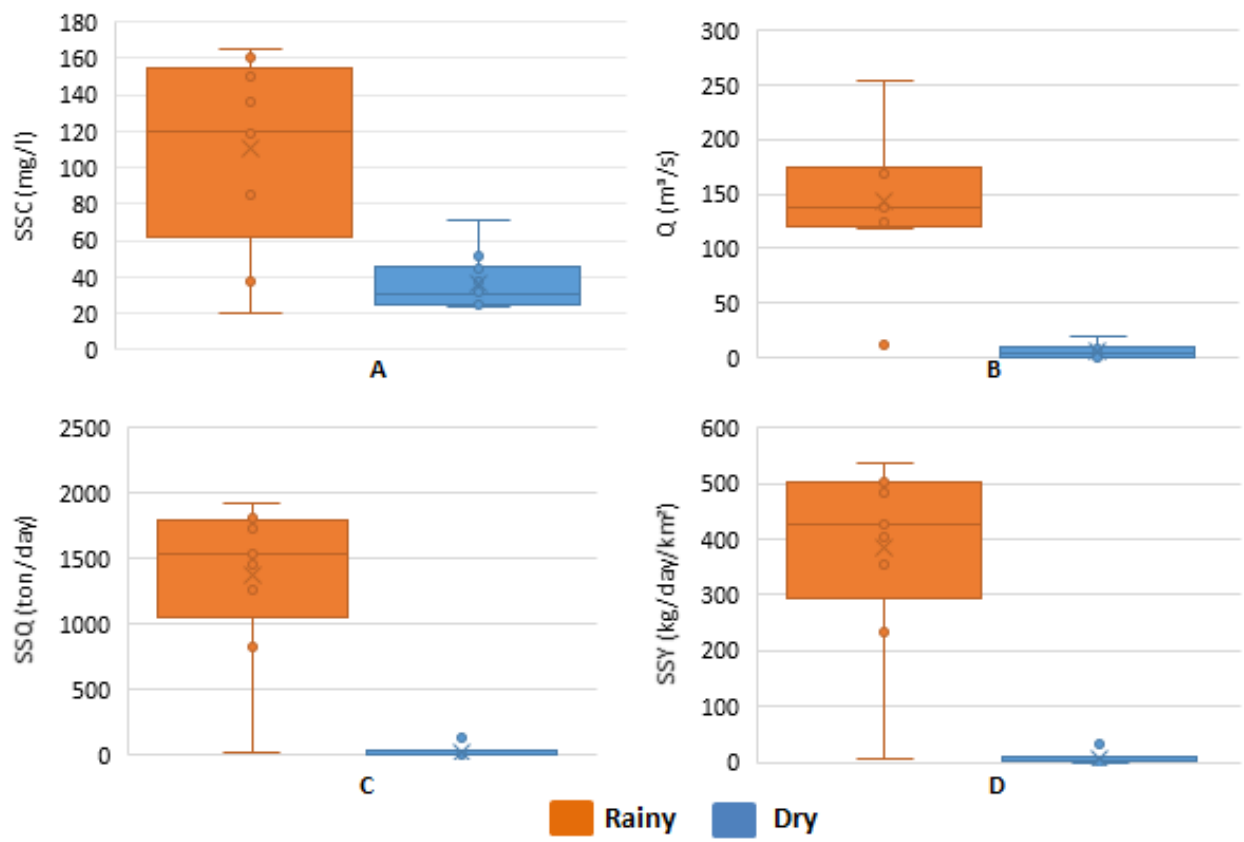

Figure 16. Boxplot of suspended sediment concentration (A), streamflow (B), suspended sediment discharge (C), and specific sediment yield (D) in different seasons along the monitoring sections of the Sororó River subbasin.

\section{Suspended sediment rating curves of the Sororó River}

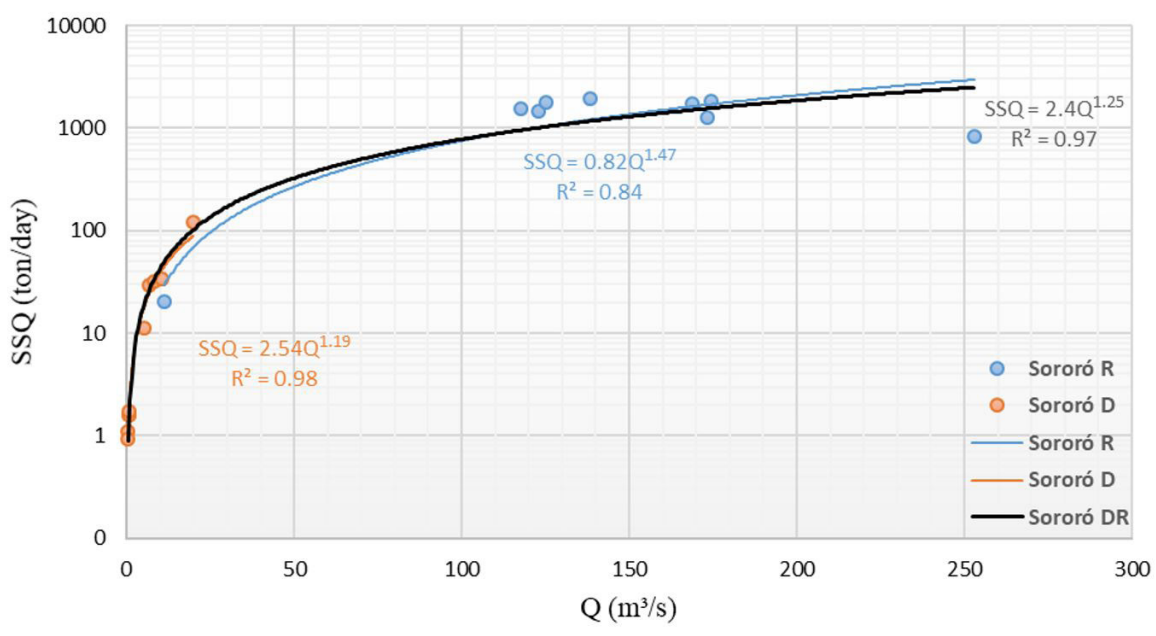

Figure 17. Sediment rating curves of the Sororó River in the rainy (R) and dry (D) seasons.

the most downstream sections (Fazenda Abadia, Fazenda Alegria, and Foz) when the lowest streamflow, sediment discharge, and specific suspended sediment yield values were obtained.

The sediment rating curves for the Itacaiúnas River for the dry season (Figure 19A) showed mostly good fits, except for the Montante Tapirapé section, which showed more scattered values.

The sediment rating curves of the rainy season for the Água Azul, Salobo and Montante Tapirapé sections had high $\mathrm{R}^{2}$ values (0.96, 0.94, and 0.87, respectively), whereas the corresponding curves of the Parauapebas Montante, Fazenda Abadia, Fazenda Alegria, and Foz sections had lower $\mathrm{R}^{2}$ values $(0.66,0.75,0.80$, and 0.74, respectively) (Figure 19B). The Montante Parauapebas,
Fazenda Abadia, Fazenda Alegria, and Foz sections received additional inputs from sedimentary discharges from the Tapirapé, Parauapebas, Vermelho, and Sororó Rivers, respectively. At a specific time, discharges of larger sediments occurred at lower streamflows (corresponding to the beginning of the rainy season), and sediment discharges decreased (upper branches of the curves) with the gradual streamflow increases.

Similar to the trend observed in the sediment rating curves of the other subbasins, when integrating all data, the fit of the sediment rating curves improved (Figure 19C). Importantly, in the intermediate portion of the sediment rating curves of the Fazenda Alegria and Foz sections, sediment discharges were 

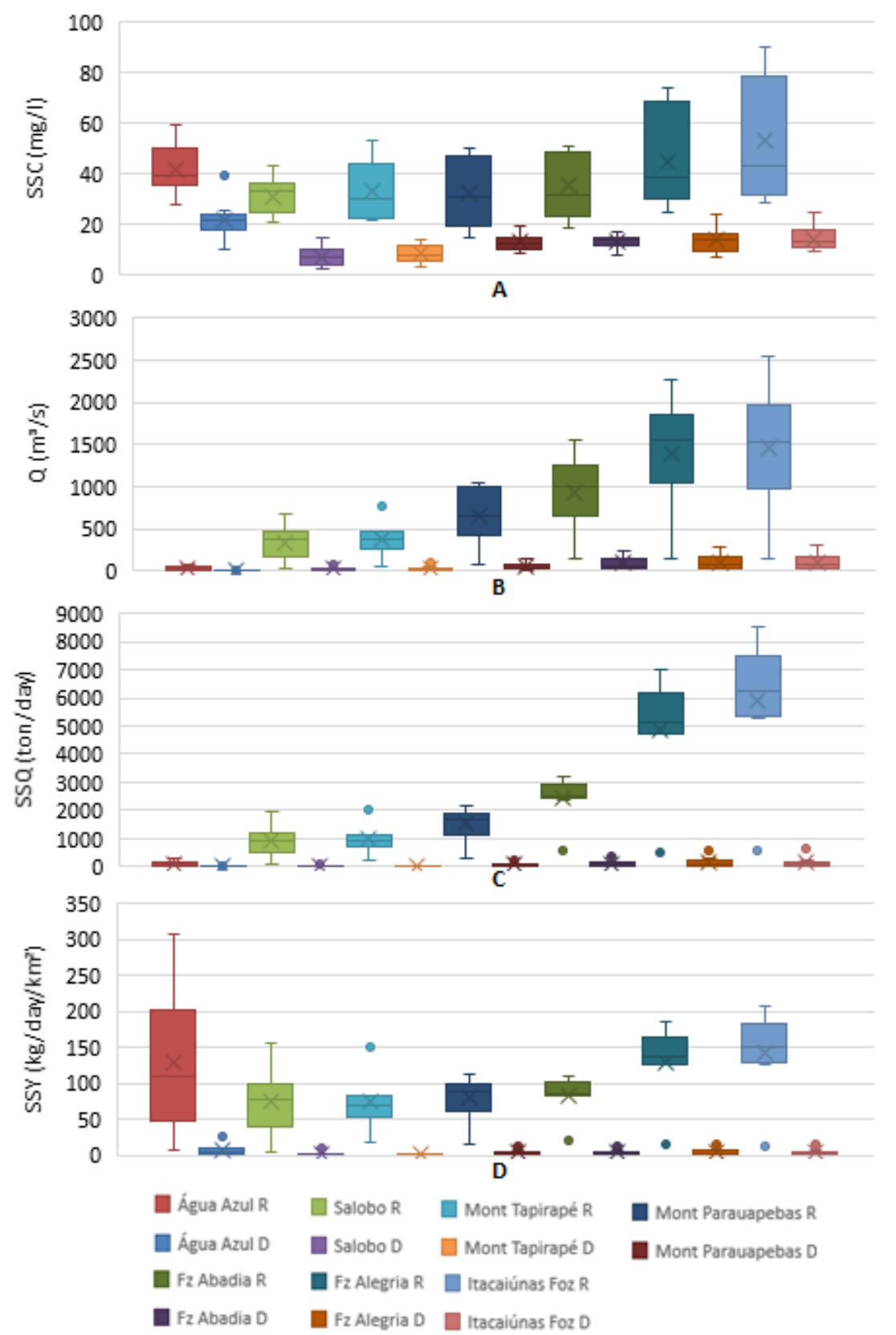

Figure 18. Boxplots of suspended sediment concentration, seasonal streamflow variation, suspended sediment discharge, and specific suspended sediment yield of the hydrosedimentological stations of the Itacaiúnas River (from upstream to downstream) from 2015 to 2019.

underestimated at streamflows ranging from 1,000 to $1,300 \mathrm{~m}^{3} / \mathrm{s}$ and overestimated at streamflows higher than $2,000 \mathrm{~m}^{3} / \mathrm{s}$. Nevertheless, the coefficients of determination and correlation of the regression equation of these sections were high, namely 0.95 and 0.85 , respectively.

\section{DISCUSSION}

\section{Comparison of the suspended sediment rating curves}

When analyzing the sediment rating curve, the separation between the rainy and dry seasons did not improve the curve fitting. The curves obtained using all data had higher determination coefficients than those using only the values of the rainy or dry season, except for two hydrosedimentological stations where the curve obtained for the dry season had a slightly higher $\mathrm{R}^{2}$ than those obtained using all data.

Considering sediment rating curves obtained using all data, the $\mathrm{R}^{2}$ varied from 0.92 (Montante Tapirapé station at Itacaiúnas River) to 0.99 (Sossego station at Parauapebas River), indicating a good fit of the power equation to SSQ and Q data for all the river sections in the IRW.

Although the $\mathrm{a}$ and $\mathrm{b}$ coefficients of the exponential sediment rating curve have no physical meaning, some physical interpretation of them is usually presented (Asselman, 2000). Morgan (1995) stated that higher values of coefficient a indicate materials that can be more easily transported. For the 

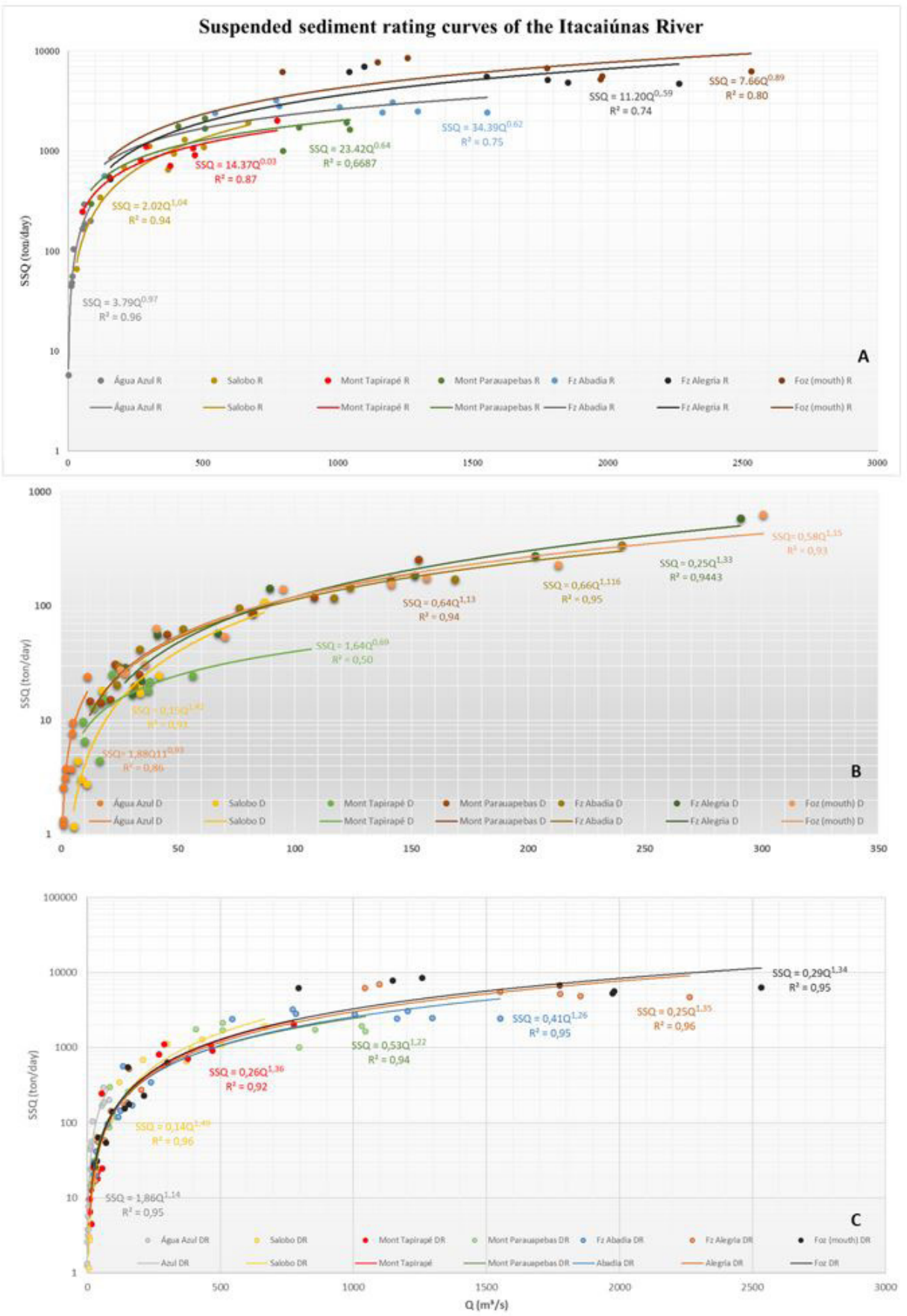

Figure 19. Suspended sediment rating curves for the Itacaiúnas River for the dry season (A), rainy season (B), and all seasons (C).

16 hydrosedimentological stations of the IRW, coefficient a ranged from 0.14 to 4.33 . Higher values were observed at the stations in the Vermelho and Sororó subbasins in the eastern IRW; these stations are in the geologic province of the Araguaia Belt, which has very friable metasedimentary rocks (shales and phyllites) and very different textural characteristics of the soils from those of the clay-silty soils in the rest of the IRW. Additionally, these 3 stations are the most deforested and are only surpassed by the Sossego station (Parauapebas River). Lower a coefficients are observed at the stations with lower percentages of deforested area: Salobo and Tapirapé; these stations are both on the Itacaiúnas River at locations where it crosses protected areas. The correlation between the a coefficients and percentage of deforested areas in the catchment area was 0.66 , and that between the a coefficients and the SSC was 0.82 . Therefore, the results are in accordance with the interpretation of Morgan (1995).

Asselman (2000) stated that the b coefficient is related to the erosive power of the river or to the extent to which new sediment sources become available when discharge increases. In the IRW, the b coefficient ranged from 0.92 (Tapirapé River) to 1.49 (Salobo station on the Itacaiúnas River). The Salobo station is located near the Serra de Carajás, which is the region in the IRB that has higher altitudes. 


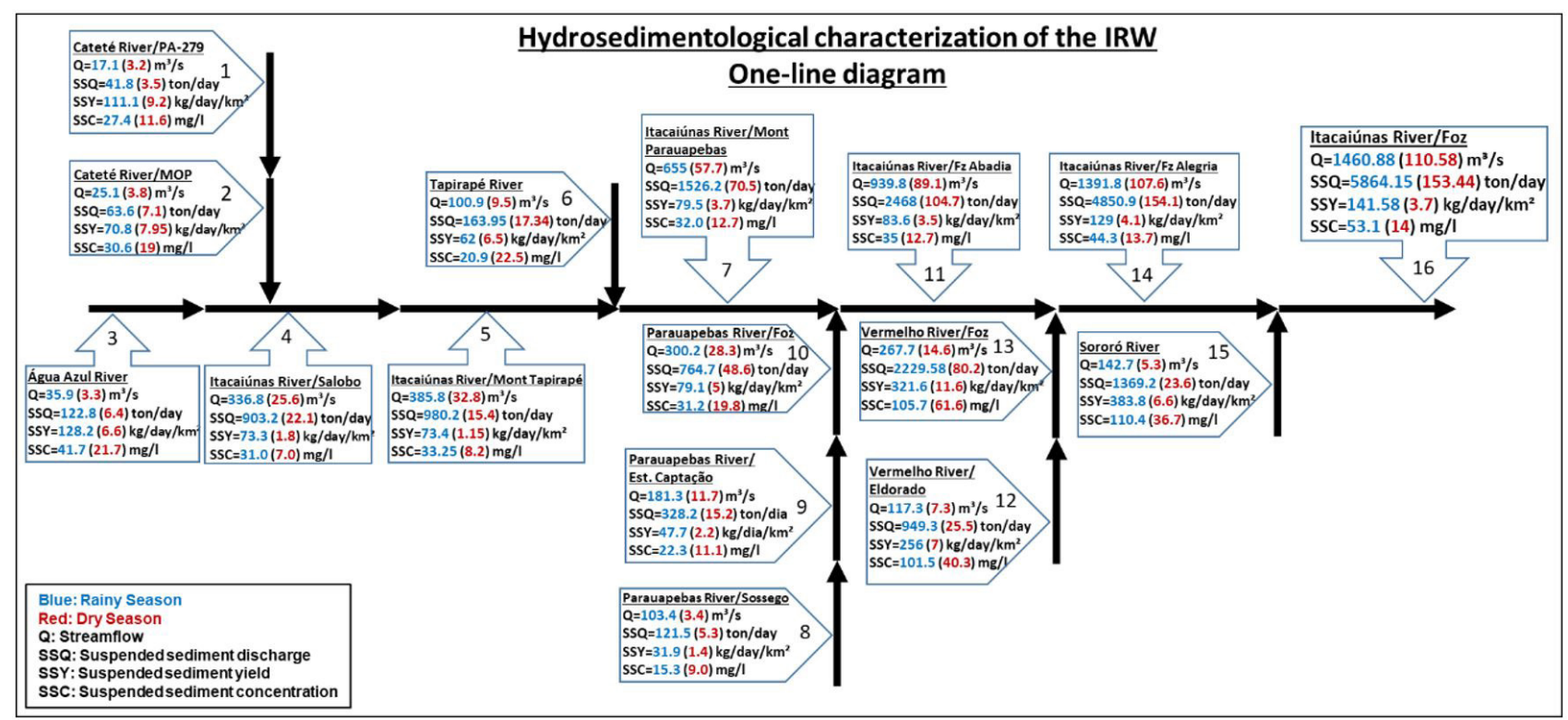

Figure 20. One-line diagram of the monitoring sections and respective mean values of the main hydrosedimentological parameters of the Itacaiúnas River Watershed.

\section{Suspended sediment through the IRW}

Figure 20 shows the one-line diagram of the IRW, which makes it possible to schematically visualize the hydrosedimentological control sections with their mean streamflow, suspended sediment discharge, specific suspended sediment yield, and SSC values for each season (rainy and dry); the diagram summarizes the assessed hydrosedimentological characteristics of the IRW by integrating all data discussed above. After receiving contributions from protected areas, especially in the dry season, the decrease in the SSY in the Itacaiúnas River (Salobo and Montante Tapirapé sections) stands out. Conversely, the high SSY values of the Vermelho and Sororó Rivers in the rainy season increase the SSY in the final stretches of the Itacaiúnas River after receiving the contributions from these tributaries.

According to the parameters adopted by ANA, in the IRW, the SSCs would be low (50 to $100 \mathrm{mg} / \mathrm{L}$ ) in the Cateté, Tapirapé, Parauapebas, and Itacaiúnas subbasins and moderate (100 to $150 \mathrm{mg} / \mathrm{L})$ in the Vermelho $(106 \mathrm{mg} / \mathrm{L})$ and Sororó subbasins $(110 \mathrm{mg} / \mathrm{L})$ by considering the mean of the rainy seasons when the highest concentrations are recorded; that is, in the dry season, the concentrations are low. In general, the average values in the rivers that make up the Itacaiúnas River basin for the concentration of suspended sediments are higher than those found by Lima et al. (2003) in the Tocantins River, which has an average concentration of $8.84 \mathrm{mg} / \mathrm{L}$; they are within the average of $27.38 \mathrm{mg} / \mathrm{L}$ in the São Francisco River (Lima, 2001); they are less than $149.33 \mathrm{mg} / \mathrm{L}$ in the Amazon River (Guyot et al., 2005); and they are $108.11 \mathrm{mg} / \mathrm{L}$ in the Paraguay River (Carvalho et al., 2005).

The specific sediment yield is low in the Tapirapé River subbasin, in the Salobo section of the Itacaiúnas River, and in the Sossego and Estação de Captação sections of the Parauapebas River; it is moderate in the Cateté River subbasin and in the Água Azul, Montante Tapirapé, Montante Parauapebas, Fazenda Abadia, Fazenda Alegria, and Itacaiúnas River Foz sections; and it is high to very high in the Vermelho and Sororó River subbasins. The Vermelho and Sororó River subbasins, which have deforestation surpassing $77 \%$ of their areas and are dominated by pasture, are the main producers of suspended sediments per drained area within the IRW. These are also the regions first deforested in the IRW.

\section{CONCLUSIONS}

The hydrosedimentological data monitoring of the IRW from March 2015 to October 2019 showed striking seasonality in the form of a rainy (November to May) and a dry season (June to October), as identified in previous rainfall analyses and schematized in the one-line diagram of Figure 16.

At the Itacaiúnas River mouth, the mean streamflow measured in the rainy season was $1,460.88 \mathrm{~m}^{3} / \mathrm{s}$, and the suspended sediment discharge was 5,864.15 tons/day. The mean streamflows and suspended sediment discharges measured in the dry season corresponded to only $7 \%$ and $2 \%$ of these values.

Although the study lacked a long data collection period, once it was limited to 4 field campaigns along 5 years (2015-2019), sediment rating curves have been properly developed, letting us estimate the suspended sediment discharges of the six subbasins that make up the IRW in different stretches and thus evaluate their spatial variation. Most equations showed a good correlation with and fit to the sampled data, including in the upper branches of the curves. The use of seasonal curves did not improve the results. The a coefficient of the exponential curve showed a strong relation with the deforestation and geological characteristics of the catchment areas.

The eastern IRW subbasins (Vermelho and Sororó River subbasins) are the main producers of suspended sediments per drained area within the IRW. Reforestation and improvement of pasture management actions should be considered for the region to reduce soil erosion and its consequences. 
As a final word, the authors would like to highlight that studies using the soil loss equation (USLE and variations) jointly with distributed hydrological modeling are presently under development in the study area. Such type of further studies deserves attention since they will allow better understanding of soil loss processes in the IRW and their relationships with environmental issues.

\section{ACKNOWLEDGEMENTS}

The authors would like to thank the members of DIPF and GABAN of Vale S.A. for the field support. This paper is a scientific product funded by Vale S.A./ITV - Itacaiúnas Project.

\section{REFERENCES}

AGÊNCIA NACIONAL DE ÁGUAS E SANEAMENTO BÁSICO - ANA. (2021). Retrieved in 2021, January 22, from https:/ / www. gov.br/ana/pt-br/assuntos/gestao-das-aguas/politica-nacional-derecursos-hidricos/sistema-de-informacoes-sobre-recursos-hidricos.

Aguiar, A. M. (2009). Análises hidrogeomorfológicas e bidrossedimentológicas para comparação de duas bacias hidrográficas contribuintes do reservatório de Itaipu (Dissertação de mestrado). Departamento de Geografia da Faculdade de Filosofia, Letras e Ciências Humanas, Universidade de São Paulo, São Paulo.

Alewell, C., Borrelli, P., Meusburger, K., \& Panagos, P. (2019). Using the USLE: chances, challenges and limitations of soil erosion modelling. International Soil and Water Conservation Research, 7(3), 203-225. http://dx.doi.org/10.1016/j.iswcr.2019.05.004.

Alvares, C. A., Stape, J. L., Sentelhas, P. C., de Moraes Gonçalves, J. L., \& Sparovek, G. (2013). Köppen's climate classification map for Brazil. Meteorologische Zeitschrift (Berlin), 22(6), 711-728. http:/ / dx.doi.org/10.1127/0941-2948/2013/0507.

Arnold, J. G., Srinivasan, R., Muttiah, R. S., \& Williams, J. R. (1998). Large area hydrologic modeling and assessment part I: model development. Journal of the American Water Resources Association, 34(1), 73-89. http://dx.doi.org/10.1111/j.1752-1688.1998.tb05961.x.

Asselman, N. E. M. (2000). Fitting and interpretation of sediment rating curves. Journal of Hydrology, 234(3-4), 228-248. http:/ / dx.doi. org/10.1016/S0022-1694(00)00253-5.

Benavidez, R., Jackson, B., Maxwell, D., \& Norton, K. (2018). A review of the (Revised) Universal Soil Loss Equation ((R)USLE): with a view to increasing its global applicability and improving soil loss estimates. Hydrology and Earth System Sciences, 22(11), 6059-6086. http://dx.doi.org/10.5194/hess-22-6059-2018.

Buarque, D. C. (2015). Simulação da geração e do transporte de sedimentos em grandes bacias: estudo de caso do rio Madeira (Tese de doutorado). Universidade Federal do Rio Grande do Sul, Porto Alegre.

Carvalho, N. O. (1994). Guia de práticas sedimentométricas. Brasília: ANEEL.
Carvalho, N. O. (2008). Hidrossedimentologia prática (2. ed., 600 p.). Rio de Janeiro: Interciência.

Carvalho, N. O., Filizola Júnior, N. P., Santos, P. M. C., \& Lima, J. E. F. W. (2000). Guia de práticas sedimentométricas (154 p.). Brasília: ANEEL.

Carvalho, N. O., Ide, C. N., Val, L. A. A., Rondon, M. A. C., Barbedo, A. G. A., \& Cybis, L. F. A. (2005). Riscos devido à degradação e agradação de solos na bacia do alto Paraguai. In Anais do $16^{\circ}$ Simpósio Brasileiro de Recursos Hídricos. São Paulo: ABRH.

Cavalcante, R. B. L., Pontes, P. R. M., Souza-Filho, P. W. M., \& Souza, E. B. (2019). Opposite effects of climate and land use changes on the annual water balance in the Amazon arc of deforestation. Water Resources Research, 55(4), 3092-3106. http:/ / dx.doi.org/10.1029/2019WR025083.

Colby, B. R. (1957). Relationship of unmeasured sediment discharge to mean velocity. Transactions - American Geophysical Union, 38(5), 708-719. http://dx.doi.org/10.1029/TR038i005p00708.

Dall'Agnol, R., Cunha, I. R. V., Guimarães, F. V., Oliveira, D. C., Teixeira, F. B. T., Feio, G. R., \& Lamarão, C. N. (2017). Mineralogy, geochemistry, and petrology of Neoarchean ferroan to magnesian granites of Carajás Province, Amazonian Craton: the origin of hydrated granites associated with charnockites. Lithos, 277, 3-32. http://dx.doi.org/10.1016/j.lithos.2016.09.032.

Empresa Brasileira de Pesquisa Agropecuária - EMBRAPA. (2006). Sistema Brasileiro de Classificação de Solos. Rio de Janeiro: EMBRAPA-SPI.

Fagundes, H. O., Fan, F. M., Paiva, R. C. D., Siqueira, V. A., Buarque, D. C., Kornowski, L. W., \& Collischonn, W. (2020a). Sediment flows in South America supported by daily hydrologichydrodynamic modeling. Water Resources Research, 1-39. http:// dx.doi.org/10.1002/essoar.10503046.2.

Fagundes, H. O., Paiva, R. C. D., Fan, F. M., Buarque, D. C., \& Fassoni-Andrade, A. C., (2020b). Sediment modeling of a largescale basin supported by remote sensing and in-situ observations. Catena, 190, http://dx.doi.org/10.1016/j.catena.2020.104535.

Fassoni-Andrade, A. C., \& Paiva, R. C. D. (2019). Mapping spatial-temporal sediment dynamics of river-floodplains in the Amazon. Remote Sensing of Environment, 221, 94-107. http://dx.doi. org/10.1016/j.rse.2018.10.038.

Feio, G. R. L., Dall'Agnol, R., Dantas, E. L., Macambira, M. J. B., Santos, J. O. S., Althoff, F. J., \& Soares, J. E. B. (2013). Archean granitoid magmatism in the Canaã dos Carajás area: implications for crustal evolution of the Carajás province, Amazonian craton, Brazil. Precambrian Research, 227, 157-185. http://dx.doi.org/10.1016/j. precamres.2012.04.007.

Garrido, J. W. A., Sousa, T. M. I., Ismael, L. L., Crispim, D. L., Ferreira, P. M. L., \& Queiroz, M. M. F. (2018). Determinação das curvas-chave de descargas de sedimentos em suspensão na bacia hidrográfica do Rio Piancó-Piranhas-Açu. Engenharia 
Sanitaria e Ambiental, 23(1), 69-75. http://dx.doi.org/10.1590/ s1413-41522018138711.

Glysson, G. D. (1987). Sediment-transport curves (Open-file Report, pp. 87-218). Reston, Virginia: USGS.

Guyot, J. L., Filizola, N. P., \& Laraque, A. (2005). Régime et bilan du flux sédimentaire de l'Amazone à Òbidos (Pará, Brésil) de 1995 à 2003. In D. E. Walling \& A. J. Chorowitz. Sediment budgets (Vol. 291, pp. 347-354). UK: IAHS.

Hamed, K. H., \& Rao, A. R. (1998). A modified Mann-Kendall trend test for autocorrelated data. Journal of Hydrology (Amsterdam), 204(14), 182-196. http://dx.doi.org/10.1016/S0022-1694(97)00125-X.

Instituto Brasileiro de Geografia e Estatística - IBGE. (2017). Censo Agro. Retrieved in 2021, January 22, from https://censos. ibge.gov.br/agro/2017/

Instituto Nacional de Meteorologia - INMET. (2021). Retrieved in 2021, January 22, from https:// portal.inmet.gov.br/dadoshistoricos.

Kendall, M. G. (1975). Rank Correlation Methods. New York: Oxford University Press.

Krysanova, V., Müller-Wohlfeil, D. I., \& Becker, A. (1996). Integrated modelling of bydrology and water quality in mesoscale watersheds (PIK Report). Germany: Potsdam Institute for Climate Impact Research.

Lima, J. E. F. W. (2001). Diagnóstico do fluxo de sedimentos em suspensão na bacia do Rio São Francisco Planaltina, DF: Embrapa Cerrados; Brasilia, DF: ANEEL/ANA.

Lima, J. E. F. W., Santos, P. M. C., Carvalho, N. O., \& Silva, E. M. (2003). Diagnóstico do fluxo de sedimentos em suspensão na Bacia Araguaia-Tocantins. Brasília, DF: ANA/ANEEL.

Lohani, A. K., Goel, N. K., \& Bhatia, K. K. S. (2007). Deriving stage-discharge-sediment concentration relationships using fuzzy logic. Hydrological Sciences Journal, 52(4), 793-807. https:// doi.org/10.1623/hysj.52.4.793.

Mann, H. B. (1945). Nonparametric tests against trend. Econometrica, 13(3), 245-259. http://dx.doi.org/10.2307/1907187.

Mendonça, M. T., Maier, C., Grimm, E. L., Merten, G. H., Netto, J. F., Boscaini, R., Rodrigues, M. F., Silva, T. P., Bastos, F., Batista, R. F., \& Fachi, S. M. (2019). Determinação da curva-chave das concentrações de sedimentos em suspensão na Bacia Do Rio Quaraí, na fronteira Oeste Do Rio Grande Do Sul. In J. González Aguilera \& A. M. Zuffo (Orgs.), Ciências exatas e da terra e a dimensão adquirida através da evolução tecnológica (2. ed., Vol. 2, pp. 1-317). Ponta Grossa: Atena.

Moderate Resolution Imaging Spectroradiometer - MODIS (2021). Retrieved in 2021, January 22, from https://modis.gsfc.nasa.gov/about

Monteiro, L. V. S., Xavier, R. P., Hitzman, M. W., Juliani, C., De Souza Filho, C. R., \& Carvalho, E. (2008). Mineral chemistry of ore and hydrothermal alteration at the Sossego iron oxide-coppergold deposit, Carajás Mineral Province, Brazil. Ore Geology Reviews, 34(3), 317-336. http://dx.doi.org/10.1016/j.oregeorev.2008.01.003.

Moraes, B. C. D., Costa, J. M. N. D., Costa, A. C. L. D., \& Costa, M. H. (2005). Variação espacial e temporal da precipitação no Estado do Pará. Acta Amazonica, 35(2), 207-214. http://dx.doi. org/10.1590/S0044-59672005000200010.

Morgan, R. P. C. (1995). Soil erosion and conservation (2nd ed.). London: Longman.

Nunes, S., Cavalcante, R. B. L., Nascimento Junior, W. R., SouzaFilho, P. W. M., \& Santos, D. (2019). Potential for forest restoration and deficit compensation in Itacaiúnas Watershed, Southeastern Brazilian Amazon. Forests, 10(5), 439. http:/ /dx.doi.org/10.3390/ f10050439.

Oliveira, S. F., \& Cabral, J. B. P. (2011) Análise da Concentração de sedimentos em suspensão e da descarga sólida da Bacia do rio Doce em Jataí GO. In: $19^{\circ}$ Simpósio Brasileiro de Recursos Hidricos (Vol. 1). Maceió, AL: ABRH.

Phillips, J. M., Webb, B. W., Walling, D. E., \& Leeks, G. J. L. (1999). Estimating the suspended sediment loads of rivers in the LOIS study area infrequent samples. Hydrological Process. Chichester, 13(7), 1035-1050. http://dx.doi.org/10.1002/(SICI)10991085(199905)13:7<1035::AID-HYP788>3.0.CO;2-K.

Pina Neto, A. N., Silva Júnior, R. O., \& Silva, M. S. (2020). Avaliação da produção e transporte de sedimentos na Bacia Hidrográfica do Rio Parauapebas, Amazônia Oriental (Produção técnica-científica ITV-DS N001/2020). Belém: ITV. http://dx.doi.org/10.29223/ PROD.TEC.ITV.DS.2020.10.PinaNeto.

RD Instruments. (2013). Workhorse Rio Grande. Retrieved in 2021, January 22, from http://www.teledynemarine.com/Documents/ Brand \%20Support/RD\%20INSTRUMENTS/Technical $\% 20$ Resources/Manuals\%20and\%20Guides/Workhorse/Rio\%20 Grande\%20ADCP\%20Guide_Sep13.pdf

Reid, I., Bathurst, J. C., Carling, P., Walling D. E., \& Webb, B. (1997). Sediment erosion, transport and deposition. In C. R. Thorne, R. D. Hey \& M. D. Newson. Applied fluvial geomorphology for river engineering and management (pp. 95-135). New York: John Wiley \& Sons.

Sahoo, P. K., Dall'Agnol, R., Salomão, G. N., da Silva Ferreira Junior, J., Silva, M. S., e Souza Filho, P. W. M., Powell, M. A., Angélica, R. S., Pontes, P. R., da Costa, M. F., \& Siqueira, J. O. (2019). High resolution hydrogeochemical survey and estimation of baseline concentrations of trace elements in surface water of the Itacaiúnas River Basin, Southeastern Amazonia: implication for environmental studies. Journal of Geochemical Exploration, 205, 106321. http://dx.doi.org/10.1016/j.gexplo.2019.06.003.

Salomão, G., Dall'Agnol, R., Sahoo, P., Ferreira-Júnior, J., Silva, M., Souza-Filho, P., Berrêdo, J. F., Nascimento-Junior, W., \& Costa, M. (2018). Geochemical distribution and thresholds values 
determination of heavy metals in stream water in the sub-basins of Vermelho and Sororó rivers, Itacaiúnas River watershed, Eastern Amazon, Brazil. Geochimica Brasiliensis, 32(2), 179-197. http:// dx.doi.org/10.21715/GB2358-2812.2018322180.

Santos, I., Fill, H. D., Sugai, M. R. V. B., Buba, H., Kishi, R. T., Marone, E., \& Lautert, L. F. C. (2001). Hidrometria aplicada (Vol. 1, 372 p.). Curitiba: LACTEC - Instituto de Tecnologia para o Desenvolvimento.

Santos, J. Y. G. (2015). Análise espaço-temporal de processos hidrossedimentológicos na Bacia do Rio Tapacurá (Pernambuco, Brasil) (Tese de doutorado). Universidade Federal de Pernambuco, Recife.

Silva Júnior, R. O., Queiroz, J. C. B., Ferreira, D. B. S., Tavares, A. L., Souza-Filho, P. W. M., Guimarães, J. T. F., \& Rocha, E. J. P. (2017). Estimativa de precipitação e vazões médias para a bacia hidrográfica do rio Itacaiúnas (BHRI), Amazônia Oriental, Brasil. Revista Brasileira de Geografia Física, 10(5), 1638-1654. http:/ /dx.doi. org/10.26848/rbgf.v.10.5.p1638-1654.

Sontek. (2018). Retrieved in 2021, January 22, from https:/ /info.xylem.com/RiverSurveyorManual.html?_ $\mathrm{ga}=2.136309041 .1628213744 .1624044107-1939132500.1624044107$

Sousa, S. D., Monteiro, L. V. S., De Oliveira, D. C., Delinardo Da Silva, M. A., Moreto, C. P. N., \& Juliani, C. (2015). O Greenstone Belt Sapucaia na região de Água Azul do Norte, Província Carajás: contexto geológico e caracterização petrográfica e geoquímica. In: P. S. Gorayeb \& A. M. M. Lima (Org.), Contribuições a geologia da Amazônia (1. ed., Vol. 9, pp. 305-328). Belém, PA: SBG-NO.

Souza-Filho, P. W. M., De Lucia Lobo, F., Barbosa Lopes Cavalcante, R., Mota, J. A., Nascimento, W. R., Santos, D. C., Novo, E. M. L. M., Barbosa, C. C. F., \& Siqueira, J. O. (2021). Land-use intensity of official mineral extraction in the Amazon region: linking economic and spatial data. Land Degradation \& Development, 32, 4, 1706-1717. http://dx.doi.org/10.1002/ldr.3810.

Souza-Filho, P. W. M., De Souza, E. B., Silva Júnior, R. O., Nascimento Junior, W. R., Versiani De Mendonça, B. R., Guimarães, J. T. F., Dall'Agnol, R., \& Siqueira, J. O. (2016). Four decades of land-cover, land-use and hydroclimatology changes in the Itacaiúnas River watershed, southeastern Amazon. Journal of Environmental Management, 167, 175-184. PMid:26686070. http://dx.doi.org/10.1016/j.jenvman.2015.11.039.

Souza-Filho, P. W. M., Nascimento Junior, W.R., Versiani de Mendonça, B. R., Silva Junior, R.O., Guimarães, J.T.F., Dall'agnol, R., \& Siqueira, J.O. (2015). Changes in the land cover and land use of the Itacaiunas river watershed, arc of deforestation, Carajas, southeastern Amazon. International Archives of the Photogrammetry, Remote Sensing and Spatial Information Sciences, XL-7/W3, 1491-1496. http:/ /dx.doi.org/10.5194/isprsarchives-XL-7-W3-1491-2015.

Souza-Filho, P., Nascimento, W., Santos, D., Weber, E., Silva, R., \& Siqueira, J. (2018). A GEOBIA approach for multitemporal land-cover and land-use change analysis in a Tropical Watershed in the Southeastern Amazon. Remote Sensing, 10(11), 1683. http:/ / dx.doi.org/10.3390/rs10111683.
Vestena, L. R. (2009). Análise da dinâmica hidrossedimentológica em uma bacia hidrográfica no sul do Brasil. Sociedade \& Natureza, Uberlândia, 21(3), 413-424. http://dx.doi.org/10.1590/S1982-45132009000300014.

Viney, N. R., \& Sivapalan, M. (1999). A conceptual model of sediment transport: application to the Avon River Basin in Western Australia. Hydrological Processes, 13(5), 727-743. http://dx.doi.org/10.1002/ (SICI)1099-1085(19990415)13:5<727::AID-HYP776>3.0.CO;2-D.

Wetzel, R. G., \& Likens, G. E. (1991). Limnological Analysis (2nd ed.). New York: Springer Verlag. http:/ /dx.doi.org/10.1007/978-1-4757-4098-1.

Williams, G. P. (1989). Sediment concentration versus water discharge during single hydrologic events in rivers. Journal of Hydrology, Toulouse, 111(1-4), 89-106. http://dx.doi.org/10.1016/00221694(89)90254-0.

Zappi, D. C. (2017). Paisagens e plantas de Carajás/Landscapes and plants of Carajás (248 p.). Belém: Instituto Tecnológico Vale.

\section{Authors contributions}

Marcio Sousa da Silva: Responsible for the paper writing, development and conclusions, including the introduction, bibliographical review, methodology, interpretation of the results, discussion, and final considerations. General review of the paper.

Rosane Lopes Cavalcante: Guided the definition of the paper objectives and methodology structuring. Additionally, contributed to and guided the interpretation of the results, discussion, and conclusions. General review of the paper.

Pedro Walfir Martins e Souza Filho: Guided the definition of the paper objectives, methodology structuring, and discussion. Additionally, contributed to and guided the interpretation of the results, discussion, and final considerations. General review of the paper.

Renato Oliveira da Silva Júnior: Contributed to the general review of the paper and discussions and field work.

Paulo Rógenes Pontes: Contributed to the general review and discussions of the paper.

Roberto Dallagnol: Guided the structuring of the paper.

Edson José Paulino da Rocha: Guided the structuring and review of the paper.

Editor in-Chief: Adilson Pinheiro

Associated Editor: Massimo Gerrero 